\title{
A linear CO chemistry parameterization in a chemistry-transport model: evaluation and application to data assimilation
}

\author{
M. Claeyman ${ }^{1,2}$, J.-L. Attié ${ }^{1,2}$, L. El Amraoui ${ }^{2}$, D. Cariolle ${ }^{3,4}$, V.-H. Peuch ${ }^{2}$, H. Teyssèdre ${ }^{2}$, B. Josse ${ }^{2}$, P. Ricaud ${ }^{1}$, \\ S. Massart ${ }^{3}$, A. Piacentini ${ }^{3}$, J.-P. Cammas ${ }^{1}$, N. J. Livesey ${ }^{5}$, H. C. Pumphrey ${ }^{6}$, and D. P. Edwards ${ }^{7}$ \\ ${ }^{1}$ Laboratoire d'Aérologie, Université de Toulouse, CNRS/INSU, Toulouse, France \\ ${ }^{2}$ CNRM-GAME, Météo-France and CNRS URA 1357, Toulouse, France \\ ${ }^{3}$ CERFACS, CNRS URA 1875, Toulouse, France \\ ${ }^{4}$ Météo-France, Toulouse, France \\ ${ }^{5}$ Jet Propulsion Laboratory, California Institude of Technology, Pasadena, California, USA \\ ${ }^{6}$ University of Edimburgh, Edinburgh, UK \\ ${ }^{7}$ National Center for Atmospheric Research, Boulder, Colorado, USA
}

Received: 26 January 2010 - Published in Atmos. Chem. Phys. Discuss.: 12 March 2010

Revised: 25 June 2010 - Accepted: 28 June 2010 - Published: 6 July 2010

\begin{abstract}
This paper presents an evaluation of a new linear parameterization valid for the troposphere and the stratosphere, based on a first order approximation of the carbon monoxide $(\mathrm{CO})$ continuity equation. This linear scheme (hereinafter noted LINCO) has been implemented in the 3-D Chemical Transport Model (CTM) MOCAGE (MOdèle de Chimie Atmospherique Grande Echelle). First, a one and a half years of LINCO simulation has been compared to output obtained from a detailed chemical scheme output. The mean differences between both schemes are about $\pm 25 \mathrm{ppbv}$ (part per billion by volume) or $15 \%$ in the troposphere and \pm 10 ppbv or $100 \%$ in the stratosphere. Second, LINCO has been compared to diverse observations from satellite instruments covering the troposphere (Measurements Of Pollution In The Troposphere: MOPITT) and the stratosphere (Microwave Limb Sounder: MLS) and also from aircraft (Measurements of ozone and water vapour by Airbus in-service aircraft: MOZAIC programme) mostly flying in the upper troposphere and lower stratosphere (UTLS). In the troposphere, the LINCO seasonal variations as well as the vertical and horizontal distributions are quite close to MOPITT CO observations. However, a bias of $\sim-40 \mathrm{ppbv}$ is observed at $700 \mathrm{hPa}$ between LINCO and MOPITT. In the stratosphere, MLS and LINCO present similar large-scale patterns, except over the poles where the $\mathrm{CO}$ concentration is underestimated by the model. In the UTLS, LINCO presents small biases
\end{abstract}

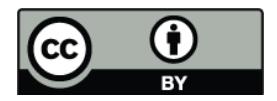

Correspondence to: $\mathrm{M}$. Claeyman (marine.claeyman@aero.obs-mip.fr) less than $2 \%$ compared to independent MOZAIC profiles. Third, we assimilated MOPITT CO using a variational 3DFGAT (First Guess at Appropriate Time) method in conjunction with MOCAGE for a long run of one and a half years. The data assimilation greatly improves the vertical CO distribution in the troposphere from 700 to $350 \mathrm{hPa}$ compared to independent MOZAIC profiles. At $146 \mathrm{hPa}$, the assimilated $\mathrm{CO}$ distribution is also improved compared to MLS observations by reducing the bias up to a factor of 2 in the tropics. This study confirms that the linear scheme is able to simulate reasonably well the $\mathrm{CO}$ distribution in the troposphere and in the lower stratosphere. Therefore, the low computing cost of the linear scheme opens new perspectives to make free runs and $\mathrm{CO}$ data assimilation runs at high resolution and over periods of several years.

\section{Introduction}

Carbon monoxide (CO) plays an important role in tropospheric chemistry and is one of the main pollutants in the atmosphere. It has also an important impact on the chemical production of tropospheric ozone $\left(\mathrm{O}_{3}\right)$ and thereby on climate change (e.g., Stevenson et al., 2006). Its main sink is the reaction with the hydroxyl radical $(\mathrm{OH})$ (Thompson, 1992). The biomass burning of natural vegetation is a significant global source of $\mathrm{CO}$ especially with hot spots in Central and South Africa, in South America and in northern Australia, along with photochemical production. Its lifetime of 1-2 months in the troposphere, and its important source

Published by Copernicus Publications on behalf of the European Geosciences Union. 
emissions (industries, transport, biomass burning) make $\mathrm{CO}$ a good tracer of pollution which is indicative of incomplete combustion. It also enables the tracking of long-distance airmass transport (Stohl et al., 2002; Staudt et al., 2001). Various studies have been carried out to characterize transport over polluted continents such as South America (e.g., Pickering et al., 1996; Freitas et al., 2005), Asia (e.g., Li et al., 2005) or Africa (e.g., Sinha et al., 2004; Guan et al., 2008).

Chemistry Transport Models (CTMs) at global scale are used for a better understanding of global atmospheric chemistry since they provide 4-D fields of chemical species. Several tens of species and hundreds of reactions are required to adequately model the chemical production and loss rates of the major active species. For example, $\mathrm{O}_{3}$ encounters different regimes in the troposphere and in the stratosphere. In the troposphere, $\mathrm{O}_{3}$ production consists of oxidation reactions between $\mathrm{OH}$ and some trace gas constituents in the presence of nitrogen oxides; whereas in the stratosphere, it is produced by a cycle initiated by photolysis of oxygen and destroyed by reactions involving nitrogen oxides, chlorine and bromine species.

Such complete schemes require a large amount of computing time which can put limitations on the model resolutions or on the duration of the feasible simulations. That is why linear ozone parameterizations have been developed for upper tropospheric and stratospheric studies, where only major ingredients of the atmospheric chemistry are taken into account (temperature and ozone amount). For example, the scheme developed by Cariolle and Déqué (1986) computes the ozone chemistry trend around a long state equilibrum defined by $\mathrm{O}_{3}$ and temperature. This parameterization has been recently updated by Cariolle and Teyssèdre (2007) and is widely used in many models, such as the ARPEGE-Climat (Action de Recherche Petite Echelle Grande Echelle) general circulation model (Déqué et al., 1994), and the European Centre for Medium-Range Weather Forecasting (ECMWF) model (Andersson et al., 2003) for operational forecasts and the ERA40 reanalysis project (Oikonomou and O'Neill, 2006). Several linear ozone parameterizations (e.g., McLinden et al., 2000; McCormack et al., 2004, 2006) were validated by Geer et al. (2007) using data assimilation in a stratosphere-troposphere model. Even if the computing capabilities have increased, linear parameterizations are useful. These parameterizations may avoid the impact of misspecified or poorly-known chemical species. By construction, such schemes have no intrinsic trend and then are useful for simulations of several years (e.g., Hadjinicolaou et al., 2005) and data assimilation (e.g., Semane et al., 2007; Massart et al., 2009).

In addition to their representation of chemical processes, CTMs may present deficiencies due to approximations in dynamic processes and in emission inventory. Chemical data assimilation can be used to overcome these deficiencies. It consists of providing consistent chemical species 4-D fields by combining in an optimal way observations and model fields (e.g., Lahoz et al., 2007; El Amraoui et al., 2004; Semane et al., 2009). These fields are well suited for the study of transport processes and budget analyses in the troposphere (Pradier et al., 2006), in the stratosphere (El Amraoui et al., 2008b) or in the Upper Troposphere-Lower Stratosphere (UTLS) (Barret et al., 2008). Because chemical linear schemes produce minimal computing cost and relative good quality of simulated fields, it is then possible to perform data assimilation over periods of several years.

The purpose of this paper is to present a new linear parameterization of the $\mathrm{CO}$ chemical distribution for the troposphere and the stratosphere, which makes possible long model runs and data assimilation. The parameterization is based on a linearization of the $\mathrm{CO}$ tendencies around an equilibrium state, which has been derived from a 2-D photochemical model similarly to the approach used for ozone (Cariolle and Déqué, 1986). This parameterization is well suited for $\mathrm{CO}$ which has a relatively simple chemistry. The $\mathrm{CO}$ linear scheme has been implemented into the Météo-France transport chemical model MOCAGE (MOdèle de Chimie Atmospherique Grande Echelle), (Peuch et al., 1999). A free model simulation forced by the ARPEGE meteorological analyses has been performed. A comparison of the model $\mathrm{CO}$ outputs with various observational datasets is done for a one and half year period from December 2003 to July 2005. In the stratosphere, the model results are compared to the space-borne Microwave Limb Sounder (MLS) observations. In the troposphere, comparisons are made using the spaceborne MOPITT (Measurements Of Pollution In The Troposphere) observations and the in situ measurements from MOZAIC (Measurements of ozone and water vapour by Airbus in-service aircraft) programme. We also compare the performances of the linear scheme to a detailed chemical scheme, RACMOBUS (Dufour et al., 2004). Besides, the CO linear scheme is used within the MOCAGE-PALM assimilation system (Massart et al., 2005) in order to assimilate the MOPITT CO data during the same period of study (from December 2003 to July 2005). Detailed comparisons of the CO analyses with independent MOZAIC and MLS CO observations are reported in order to validate the experiment.

This paper is organized as follows. In Sect. 2, we describe the CO linear parameterization, the CTM model, the data assimilation system employed as well as the different datasets used in this study. In Sect. 3, we discuss the results obtained for the validation of the free run with the linear $\mathrm{CO}$ chemical scheme. Section 4 presents and validates the analyses of one year of MOPITT CO data assimilation. Lastly, summary and conclusions are presented in Sect. 5. 


\section{Model and data descriptions}

\subsection{The linear carbon monoxide chemical scheme}

The new linear scheme for the computation of the $\mathrm{CO}$ chemical tendencies relies on a methodology similar to the approach developed by Cariolle and Déqué (1986) and updated by Cariolle and Teyssèdre (2007) for stratospheric ozone. The CO continuity equation is expanded into a Taylor series up to the first order around the local value of the $\mathrm{CO}$ mixing ratio $r_{\mathrm{CO}}$ and the temperature $T$ :

$\partial r_{\mathrm{CO}} / \partial t=A_{1}+A_{2}\left(r_{\mathrm{CO}}-A_{3}\right)+A_{4}\left(T-A_{5}\right)$

where the $A_{i}$ terms are monthly averages calculated using the 2-D photochemical model MOBIDIC (MOdèle BIDImensionnel de Chimie) (Cariolle et al., 2008):

$$
\begin{aligned}
& A_{1}=\overline{(P-L)} \text { : production minus loss rate of } \mathrm{CO} \\
& A_{2}=\overline{\partial(P-L) / \partial r_{\mathrm{CO}}} \text { : zonal net variation of }(P-L) \text { due } \\
& \text { to } r_{\mathrm{CO}} \text { variations }
\end{aligned}
$$

$A_{3}=\overline{r_{\mathrm{CO}}}$ : CO zonal mixing ratio

$A_{4}=\overline{\partial(P-L) / \partial T}$ : zonal net variation of $(P-L)$ due to $T$ variations

$A_{5}=\bar{T}$ : zonal mean temperature

with $P$ and $L$ being the CO production and loss terms, respectively.

The partial derivatives $A_{2}$ and $A_{4}$ in Eq. (1) are obtained by perturbing the 2-D model fields by $\pm 10 \%$ for the $\mathrm{CO}$ mixing ratio and by $\pm 10 \mathrm{~K}$ for temperature, respectively. For each month, a set of zonal mean coefficients is obtained. To test the accuracy of the linearity of the system, we have applied perturbations (up to $\pm 30 \%$ for $\mathrm{CO}$ and $\pm 20 \mathrm{~K}$ for temperature), and have found very small deviations in the calculated $A_{i}$.

Figure 1a shows the $A_{3}$ term for the month of January. It represents the zonal mean distribution of $\mathrm{CO}$ from the MOBIDIC model. This CO distribution is characterized by larger mixing ratios within the range of 100-130 ppbv (part per billion by volume) in the troposphere of Northern Hemisphere $(\mathrm{NH})$ and in the lower tropical troposphere. Large vertical gradients are observed near the UTLS region with mixing ratios below $30 \mathrm{ppbv}$ in the lower stratosphere. This CO distribution is comparable to current measurements (e.g., Edwards et al., 2003).

The $A_{1}$ term in Fig. $1 \mathrm{~b}$ gives the chemical tendencies needed to balance those due to transport and surface emissions of $\mathrm{CO}$. As expected, this term is negative and large at the equator in the lower troposphere in the presence of large biomass burning and anthropogenic emissions, and rapid vertical transport by the rising branch of the mean meridional circulation and by convection.
The photochemical relaxation time of $\mathrm{CO}$, is given by $\tau=-1 / A_{2}$ (Fig. 1c). Since the CO lifetime is mainly controlled by its reaction with $\mathrm{OH}$, the distribution of $\tau$ is closely linked to the $\mathrm{OH}$ concentrations. The lowest values of $\tau$, less than 30 days, are found in the equatorial lower troposphere, and in the middle stratosphere outside of the polar vortex $(90 \mathrm{~S}-60 \mathrm{~N})$. From the surface up to the tropopause, the $\mathrm{CO}$ relaxation time increases to reach a relative maximum of about 100 days at the equator. At summertime in southern latitudes (90 S-50 S) $\tau$ increases to values up to one year in the UTLS. At high latitudes in the NH from 0 to $30 \mathrm{~km}, \tau$ tends to infinity and $\mathrm{CO}$ becomes an inert tracer. Note that for implementation within global models, the $\mathrm{CO}$ parameterization is complemented with surface emissions and deposition in a similar way to what is done when a detailed chemical scheme is used (see Sect. 2.2).

\subsection{MOCAGE-PALM}

MOCAGE is a three-dimensional chemistry transport model for the troposphere and stratosphere (Peuch et al., 1999) which simulates interactions between dynamical, physical and chemical processes. MOCAGE uses hybrid vertical levels from the surface up to $5 \mathrm{hPa}$ with a resolution of about $150 \mathrm{~m}$ in the lower troposphere ( $40 \mathrm{~m}$ near the surface) and up to $800 \mathrm{~m}$ in the lower stratosphere. Hybrid vertical levels are designed so that lowermost levels follow the terrain while upper levels are isobaric. The version of MOCAGE used in this study has an horizontal resolution of $2^{\circ} \times 2^{\circ}$ over the globe and uses a semi-Lagrangian advection scheme (e.g., Josse et al., 2004) to transport the chemical species. Turbulent diffusion is calculated with the scheme of Louis (1979) and convective processes with the scheme of Bechtold et al. (2001). The meteorological analyses of MétéoFrance, ARPEGE (Courtier et al., 1991) were used to force the dynamics of the model every 6 hours.

The linear scheme is compared to the detailed scheme of MOCAGE, RACMOBUS which is a combination of the stratospheric scheme REPROBUS (Lefèvre et al., 1994) and of the tropospheric scheme RACM (Stockwell et al., 1997). It includes 119 individual species with 89 prognostic variables and 372 chemical reactions. The simulations presented here use the emissions inventory from Dentener et al. (2005). For $\mathrm{CO}$, emissions are given as a monthly mean for biomass burning and a yearly mean for others. Emission rates and deposition velocities are computed externally (Michou and Peuch, 2002) and taken into account in MOCAGE. The dry deposition scheme is based upon the Wesley (1989) scheme. The wet deposition is parameterized for stratiform and convective clouds (Giorgi and Chameides, 1986; Mari et al., 2000) and validated in Michou et al. (2004). MOCAGE is used for several applications: operational chemical weather forecasting in Météo-France (Dufour et al., 2004) and data assimilation research (e.g., El Amraoui et al., 2008b; Semane et al., 2009). A detailed validation of the model 


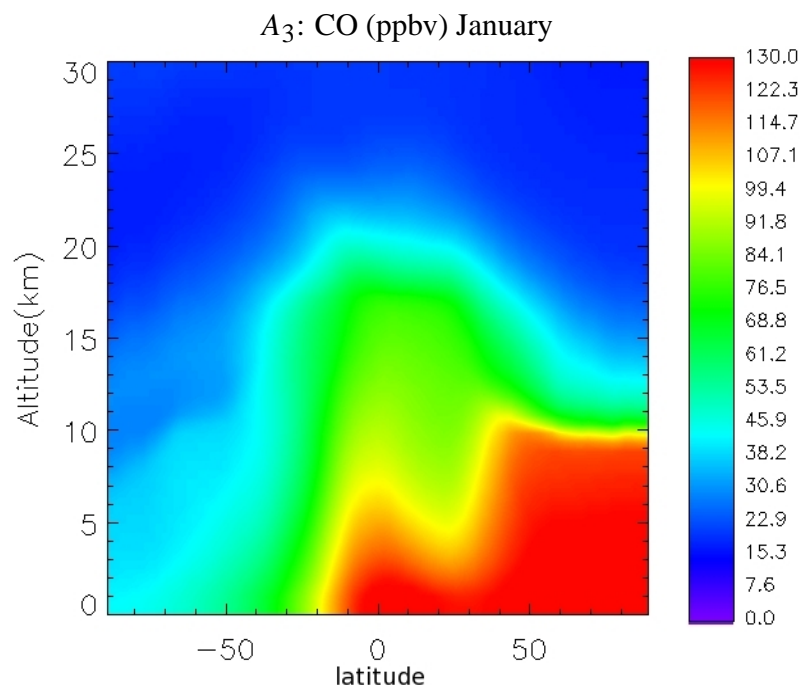

(a)

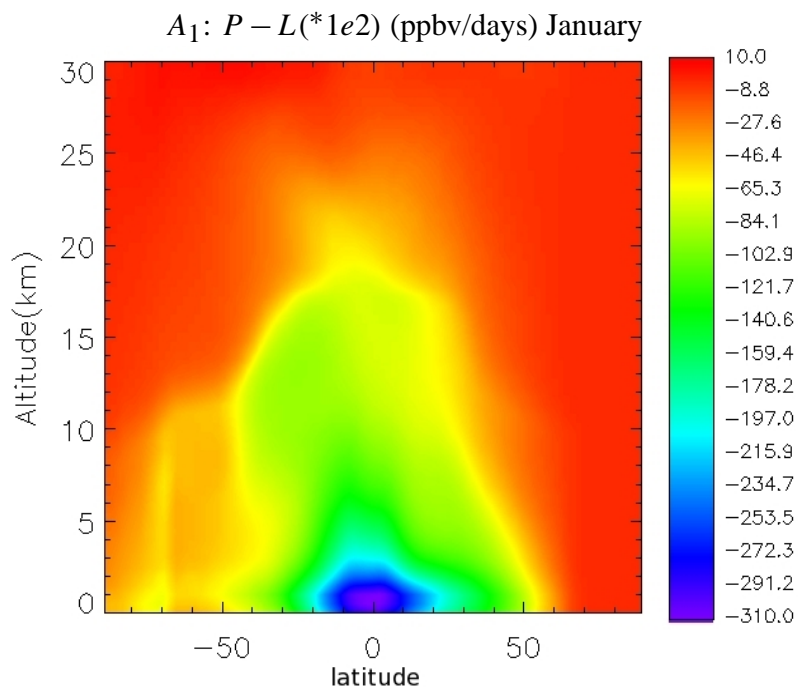

(b)

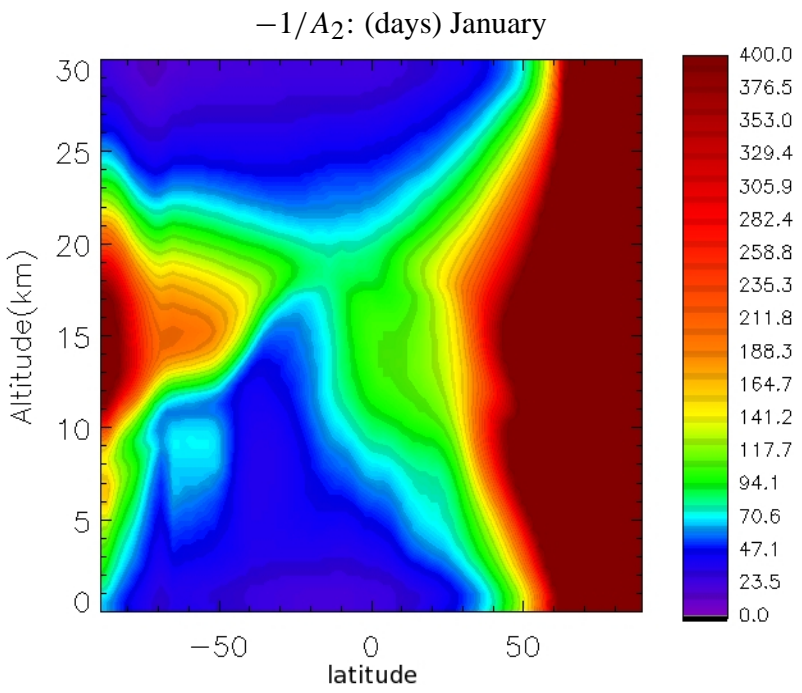

(c)

Fig. 1. (a) Background CO distribution in parts per billion by volume (ppbv), (b) net photochemical rate (ppbv/days) and (c) photochemical relaxation time (days) as a function of altitude and latitude for the month of January.

has been done using a large number of measurements during the Intercontinental Transport of Ozone and Precursors (ICARTT/ITOP) campaign (Bousserez et al., 2007). Its climate version has also been validated over several years by Teyssèdre et al. (2007).

In addition, we used the assimilation system MOCAGEPALM (Massart et al., 2005). The assimilation module is PALM (Buis et al., 2006) within which is implemented the 3D-FGAT (First Guess at Appropriate Time) assimilation technique (Fisher and Andersson, 2001). This technique is a compromise between the 3D-Var and the 4D-Var. It has been validated during the assimilation of ENVISAT data project (ASSET) and has producted good quality results compared to independent data and many other assimilation systems (Geer et al., 2006). Details on the method and on the assimilation system can be found in Massart et al. (2005), Massart et al. (2007) and El Amraoui et al. (2010).

\subsection{The Measurements}

\subsubsection{MOPITT}

The MOPITT (Measurements Of Pollution In The Troposphere) instrument is a nadir infrared correlation radiometer onboard the NASA Terra Satellite (Drummond and Mand, 1996). It has been monitoring CO from March 2000 to date. It provides global coverage in about 3 days. The pixel size is $22 \mathrm{~km} \times 22 \mathrm{~km}$ and the vertical profiles are retrieved on 7 pressure levels (surface, 850, 700, 500, 350, 250 and 
$150 \mathrm{hPa}$ ). The maximum a posteriori algorithm (Deeter et al., 2003) is used to retrieve CO from MOPITT measured radiances. It is a statistical combination of the measurement and the a priori information based on an optimal estimation method (Rodgers, 2000). The retrieved profiles are characterized by their averaging kernel matrix, which indicates the sensivity of the MOPITT measurements to the true $\mathrm{CO}$ profile. In this study, we select MOPITT CO (Version 3) retrieved profiles with less than $40 \%$ a priori contamination to ensure good quality of dataset validation (Emmons et al., 2009). The accuracy of MOPITT CO retrieved profiles is assumed to be less than $20 \mathrm{ppbv}$ for all of the 7 levels according to Emmons et al. (2004).

\subsubsection{MLS}

The Microwave Limb Sounder (MLS) (Waters et al., 2006) onboard the Aura spacecraft was launched on 15 July 2004 and placed into a near-polar Earth orbit at $\sim 705 \mathrm{~km}$ with an inclination of $98^{\circ}$ and an ascending mode at $13: 45 \mathrm{~h}$. It orbits the Earth around 14 times per day and provides dense spatial coverage for a limb sounder with daily 3500 profiles, between $82^{\circ} \mathrm{N}$ and $82^{\circ} \mathrm{S}$. MLS observes thermal microwave emission from Earth's limb in five spectral regions from $118 \mathrm{GHz}$ to $2.5 \mathrm{THz}$. The MLS CO measurements are made in the $240 \mathrm{GHz}$ region. The optimal estimation method is used to retrieve CO profiles (Rodgers, 2000). The retrieval grid has 6 levels per pressure decade for altitudes below $0.1 \mathrm{hPa}$ and 3 levels per pressure decade above this. The MLS CO level 2 products used in this paper are produced by version 2.2 of the data processing algorithms. The vertical resolution of MLS CO retrieved profiles is about 3-4 km in the stratosphere and the horizontal resolution is between $500 \mathrm{~km}$ for lower stratospheric levels and $300 \mathrm{~km}$ for upper stratospheric levels. Data are selected according to quality flag criteria presented in Livesey et al. (2007). In the version used in this study, the impact of extra terrestrial signals generated by the Milky Way and affecting the terrestrial CO retrieval mainly at $22 \mathrm{hPa}$ for some specific days of year and latitudes has been eliminated according to Pumphrey et al. (2009). The MLS CO data set was validated by Livesey et al. (2008) for the upper troposphere and lower stratosphere and by Pumphrey et al. (2007) for the stratosphere and the mesosphere where the accuracy was estimated to be $30 \mathrm{ppbv}$ for pressures of $147 \mathrm{hPa}$ and less.

\subsubsection{MOZAIC}

The MOZAIC (Measurements of ozone and water vapour by Airbus in-service aircraft) programme (Marenco et al., 1998) was launched in January 1993. The project results from the collaboration of the aeronautics industry, airline carriers, and research laboratories. Measurements started in August 1994, with the installation of ozone and water vapor sensors aboard five commercial aircrafts. In 2001, the in- strumentation was upgraded by installing $\mathrm{CO}$ sensors on all aircrafts. For the measurement of $\mathrm{CO}$, the IR gas filter correlation technique is employed (Thermo Environmental Instruments, Model 48CTL). This IR instrument provides excellent stability, which is important for continuous operation without frequent maintenance. The sensitivity of the instrument was improved by several modifications (Nédélec et al., 2003 ), achieving a precision of $5 \mathrm{ppbv}$ or $5 \%$ for a $30 \mathrm{~s}$ response time. The majority of these flights are in the $\mathrm{NH}$ and connect Europe, North America and eastern Asia, but also include flights to South America and Africa. About $90 \%$ of the MOZAIC measurements are made at cruise altitude, between 9 and $12 \mathrm{~km}$. The remaining measurements are performed during ascent and descent phases. A complete description of the MOZAIC programme may be found at http: //mozaic.aero.obs-mip.fr/web/ and in the IGAC Newsletters (Cammas and Volz-Thomas, 2007). We selected MOZAIC data from flights over Europe, North America and Eastern Asia.

\section{Evaluation of the linear $\mathrm{CO}$ chemical scheme}

In order to evaluate the linear $\mathrm{CO}$ chemical scheme, two MOCAGE simulations have been made in the period between 1 December 2003 and 1 July 2005. The first one (hereinafter referred to as LINCO) used the linear CO parameterization and the second one used the detailed chemical scheme RACMOBUS. All the other model components are kept the same: in particular, they both used the same atmospheric forcing from ARPEGE analysis and the same emission inventory. The simulated field for 1 December 2003 has been obtained from a free run with RACMOBUS started from the October climatological initial field. Independent observations are used to evaluate LINCO: measurements from MOPITT in the troposphere, MLS in the stratosphere and MOZAIC in the UTLS.

\subsection{Comparison with the detailed chemical scheme RACMOBUS}

In this section, we evaluate the effect of $\mathrm{CO}$ chemistry representation in the model (detailed or linearized), by comparing two simulations. Both RACMOBUS and LINCO use the same model components (e.g., transport, atmospheric processes and emissions). In Fig. 2, we present the temporal evolution of the CO zonal mean obtained from LINCO and RACMOBUS for the period from December 2003 to June 2005 at the pressure levels 850 and $150 \mathrm{hPa}$, in the lowermost and uppermost troposphere respectively. Qualitatively, the two schemes behave similarly with differences between schemes of about $\pm 20 \%$, never exceeding $\pm 40 \%$. However, at the beginning of the period, LINCO concentrations tend to be higher than RACMOBUS CO concentrations whereas elsewhere, the opposite behavior is observed at both 

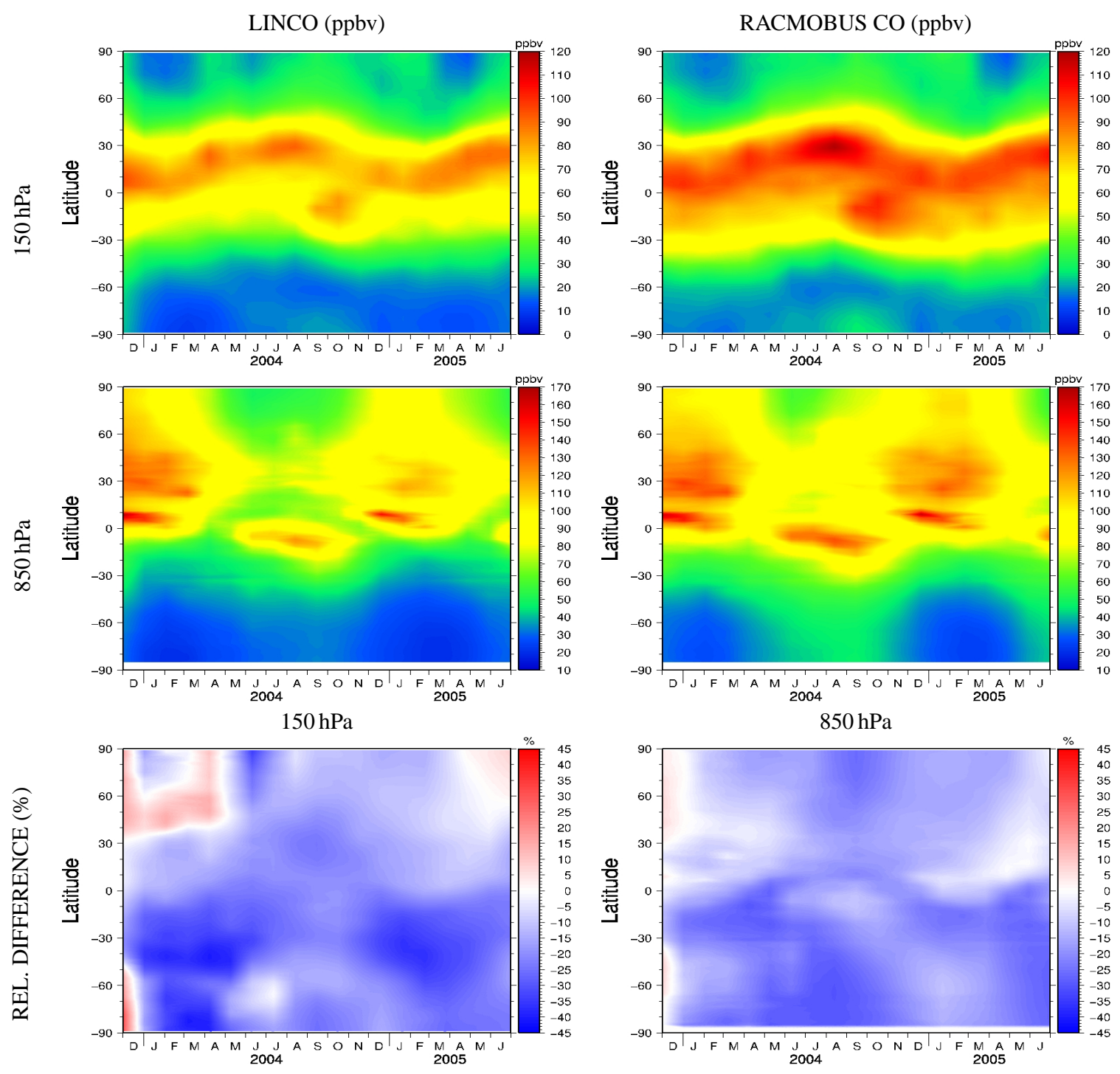

Fig. 2. LINCO (left) and RACMOBUS (right) zonal mean of CO in parts per billion by volume (ppbv) from December 2003 to June 2005 at $150 \mathrm{hPa}$ (top) and $850 \mathrm{hPa}$ (middle). Corresponding relative differences (LINCO-RACMOBUS)/RACMOBUS x100 in \% are plotted at bottom at $150 \mathrm{hPa}$ (left) and $850 \mathrm{hPa}$ (right).

pressure levels: RACMOBUS CO concentrations are higher. The differences between both schemes are lower in the $\mathrm{NH}$ than in Southern Hemisphere (SH). Note that the schemes have different approaches. On the one hand, RACMOBUS is a detailed chemical scheme for which $\mathrm{CO}$ is interdependent with other species, particularly the hydroxyl radical $(\mathrm{OH})$. On the other hand, the CO concentration from LINCO is controlled by fixed zonal coefficients based on 2-D model outputs (see Sect. 2.1).

Figure 3 presents $\mathrm{CO}$ zonal means obtained from LINCO and RACMOBUS for two specific months (July 2004 and January 2005) representative of NH summer and winter, respectively. Both chemical schemes have similar patterns with small differences. The distribution of $\mathrm{CO}$ from both schemes reproduces the impact of African biomass burning emissions in the tropics. In the same way, the two schemes capture the mesospheric subsidence of $\mathrm{CO}$ within the stratospheric polar vortex (latitudes poleward of $60^{\circ}$ ) evidenced by high $\mathrm{CO}$ concentrations between 25 and $30 \mathrm{~km}$. For both months, concentrations in LINCO are lower than those in RACMOBUS in the troposphere but the differences do not exceed $\sim 25 \mathrm{ppbv}(\sim 35 \%)$. The maxima of the difference between both schemes in the troposphere, are located in the region with the intense convective activity, namely the intertropical convergence zone.

The negative bias observed in the troposphere between RACMOBUS and LINCO may come from 4 causes. The first hypothesis could be a negative bias between RACMOBUS 

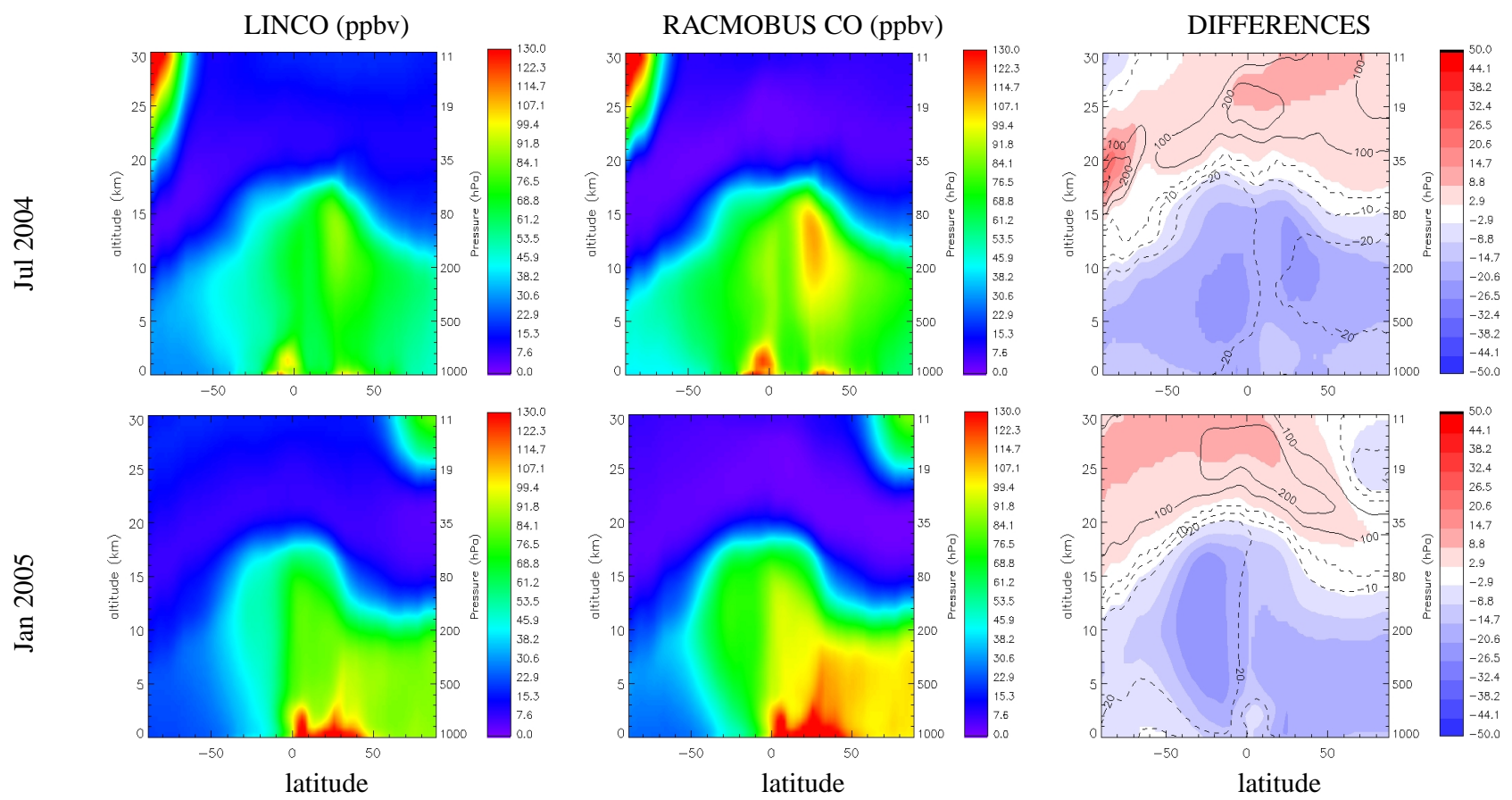

Fig. 3. Zonal monthly mean of CO from LINCO and RACMOBUS in parts per billion by volume (ppbv) and difference (LINCORACMOBUS) (ppbv) on July 2004 (top) and January 2005 (bottom). The isolines correspond to the relative difference of LINCO and RACMOBUS (LINCO-RACMOBUS)/RACMOBUS X100 in \%.

average values and the $A_{3}$ coefficient which would lead LINCO to relax towards too low CO concentrations. Figures $1 \mathrm{a}$ and 3 show that the opposite is actually observed: the $A_{3}$ coefficient is larger than RACMOBUS and, on the contrary, $A_{3}$ tends to increase the concentrations in LINCO. The second hypothesis is a bias between the $A_{5}$ LINCO coefficient and the ARPEGE temperature analyses used in MOCAGE. The comparison of these two terms shows that the differences are of the order of $1 \mathrm{~K}$ and the $A_{4}$ coefficient values are small in the troposphere, leading to a small contribution of the temperature term $A_{4}\left(T-A_{5}\right)$ in comparison to the other coefficients. The third hypothesis is an inconsistency between the production minus loss rate ( $A_{1}$ coefficient) and the transport in MOCAGE since the MOCAGE and MOBIDIC models are different: the first one is a 3-D CTM and the second is a 2-D photochemical model. The fourth hypothesis comes from the different emission representations of MOBIDIC and MOCAGE. MOCAGE uses an emission inventory whereas MOBIDIC is relaxed to a climatology at the surface. This could introduce a too strong destruction of CO in the LINCO scheme. Moreover, the approach developed for the LINCO scheme is slightly different from that of the linear ozone scheme (Cariolle and Déqué, 1986) in the sense that for LINCO, the emissions are taken into account whereas for linear ozone there are no emissions. Consequently, the "production loss" term $\left(A_{1}\right)$ should also be balanced with the emissions.
The three first hypotheses have already been studied in the context of linear ozone schemes (e.g. McCormack et al., 2006; Coy et al., 2007; Geer et al., 2007) whereas the emission effect in the LINCO scheme is something entirely new. To confirm an inconsistency in the $A_{1}$ coefficient, we made a sensitive test (not shown) by increasing the $A_{1}$ coefficient of LINCO. This test shows that by changing arbitrarily the $A_{1}$ coefficient, the bias between LINCO and RACMOBUS can be reduced in the troposphere. However, the $A_{1}$ LINCO coefficient is not anymore consistent with the chemistry and physics of the other coefficients calculated with MOBIDIC. Furthermore, the $\mathrm{CO}$ interannual variability is typically of $10-20 \%$ in the free troposphere, and nothing indicates that the tuning for a specific period could improve results for integrations of several years. Therefore, we decided to keep the set of coefficients calculated with MOBIDIC in the next sections.

In the stratosphere, LINCO concentrations are higher than RACMOBUS except between $70^{\circ} \mathrm{S}$ and $90^{\circ} \mathrm{S}$ in July 2004 and between $60^{\circ} \mathrm{N}$ and $90^{\circ} \mathrm{N}$ in January 2005. In these regions, LINCO underestimates the $\mathrm{CO}$ concentration of the mesospheric descent compared to RACMOBUS. The absolute difference in the stratosphere is about $\sim 15 \mathrm{ppbv}$ $(\sim 200 \%)$. Note that CO concentrations are generally very low in RACMOBUS in the stratosphere compared to LINCO, which explains such high relative differences between both schemes in the stratosphere. The positive bias 


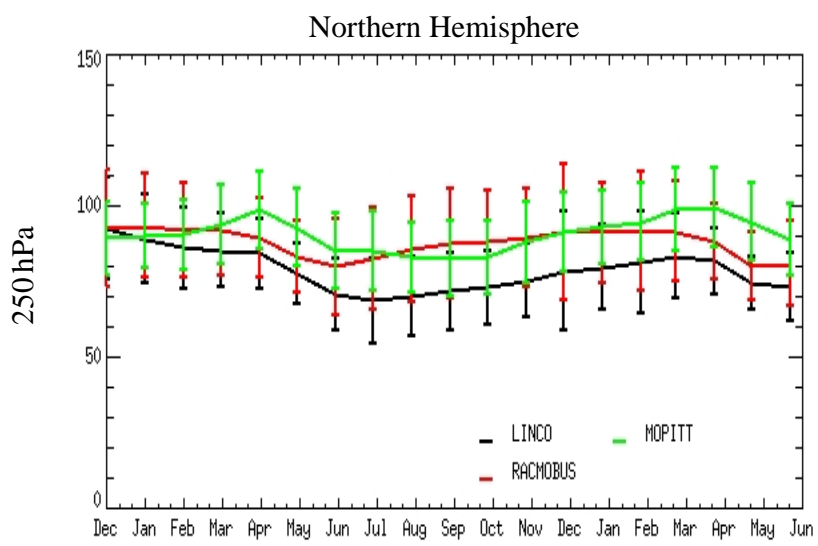

(a)

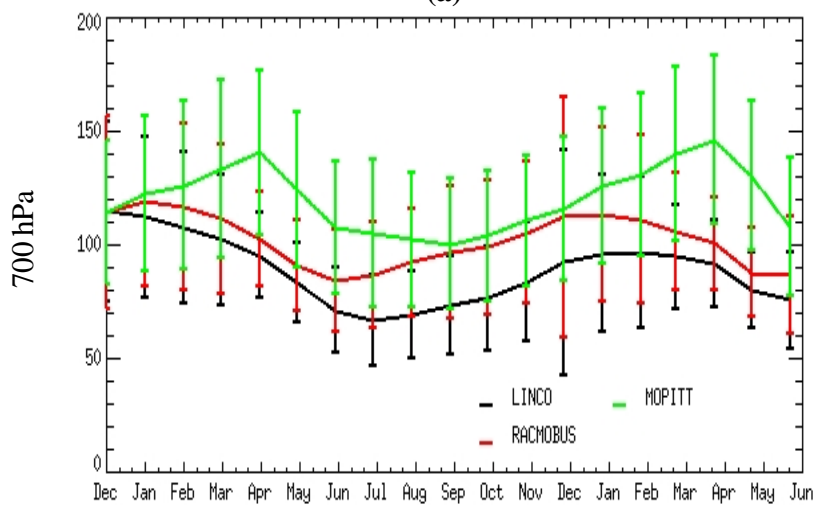

(c)

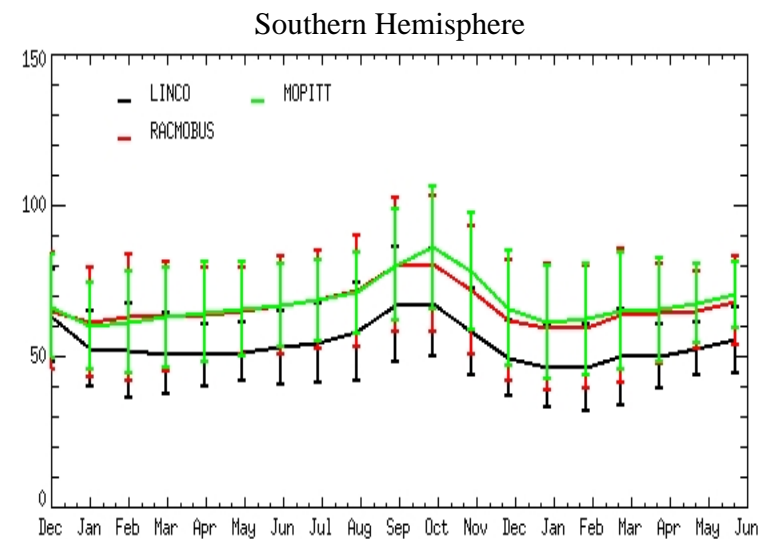

(b)

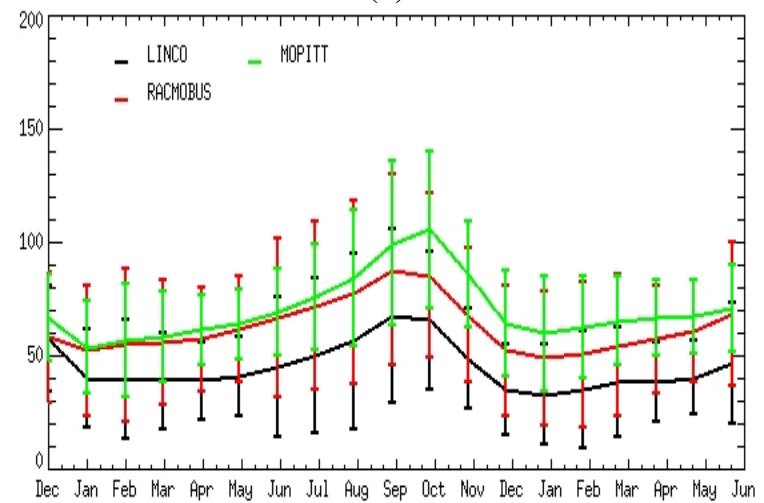

(d)

Fig. 4. CO fields in parts per billion by volume (ppbv) calculated by LINCO (black lines) and by RACMOBUS (red lines) and retrieved from MOPITT measurements (green lines) for NH (a) (left) and SH (b) (right) at $250 \mathrm{hPa}$ (upper panel) and at $700 \mathrm{hPa}$ (c) and (d) (lower panel). Note that modeled CO fields have been smoothed by MOPITT averaging kernels.

observed between RACMOBUS and LINCO may be explained by the positive bias between the $A_{3}$ LINCO coefficient (Fig. 1a) and RACMOBUS (Fig. 3) in the stratosphere which relax LINCO concentrations to higher values. Moreover, the production minus loss rate in the stratosphere (Fig. 1b, $A_{1}$ coefficient) is positive which may also contribute to the positive bias between RACMOBUS and LINCO.

In the following sections, we evaluate the LINCO fields in comparison to independent data from satellites and in situ measurements.

\subsection{Comparison with satellite data in the troposphere}

Figure 4 shows the time evolution of $\mathrm{CO}$ from December 2003 to June 2005 as obtained by LINCO, RACMOBUS and MOPITT measurements at 700 and $250 \mathrm{hPa}$ in the $\mathrm{NH}$ and $\mathrm{SH}$. Note that modeled $\mathrm{CO}$ fields have been smoothed by MOPITT averaging kernels in order to take into account the vertical resolution and the a priori information used in the retrieval process of the V3 MOPITT product. At $700 \mathrm{hPa}$ (Fig, 4c and d), the seasonal CO variations are fairly well represented by both chemical schemes showing a maximum in April in the $\mathrm{NH}$ and a maximum in October in the $\mathrm{SH}$.
April maximum in the $\mathrm{NH}$ is due to the very weak sunshine during winter and correspondingly less destruction of $\mathrm{CO}$ by $\mathrm{OH}$ leading to the buildup of $\mathrm{CO}$ because of its long lifetime. In addition, in the $\mathrm{SH}$, this period corresponds to an intense biomass burning activity in South Africa and later on in Australia (Edwards et al., 2006). However, the LINCO scheme presents lower concentrations than RACMOBUS and MOPITT in both hemispheres. As already explained in the Sect. 3.1, this suggests a larger destruction of CO in LINCO compared to RACMOBUS and MOPITT retrievals. The bias between MOPITT and LINCO is about $30-40$ ppbv in the $\mathrm{NH}$ and 20-30 ppbv in the SH. However, LINCO follows very well the variations seen in MOPITT CO retrievals with a constant bias. RACMOBUS scheme seems to have a better $\mathrm{CO}$ time evolution in the $\mathrm{SH}$ than in the $\mathrm{NH}$ where emissions patterns and variability as well as photochemistry are more complex. Even if the bias between RACMOBUS and MOPITT is very low in the $\mathrm{SH}$ and at $250 \mathrm{hPa}$ in the $\mathrm{NH}$, a negative bias between RACMOBUS and MOPITT is observed in the $\mathrm{NH}$ at $700 \mathrm{hPa}$ which can reach $30 \mathrm{ppbv}$. The bias between measured and modeled $\mathrm{CO}$ fields also suggests that $\mathrm{CO}$ emissions used in the model are underestimated. 

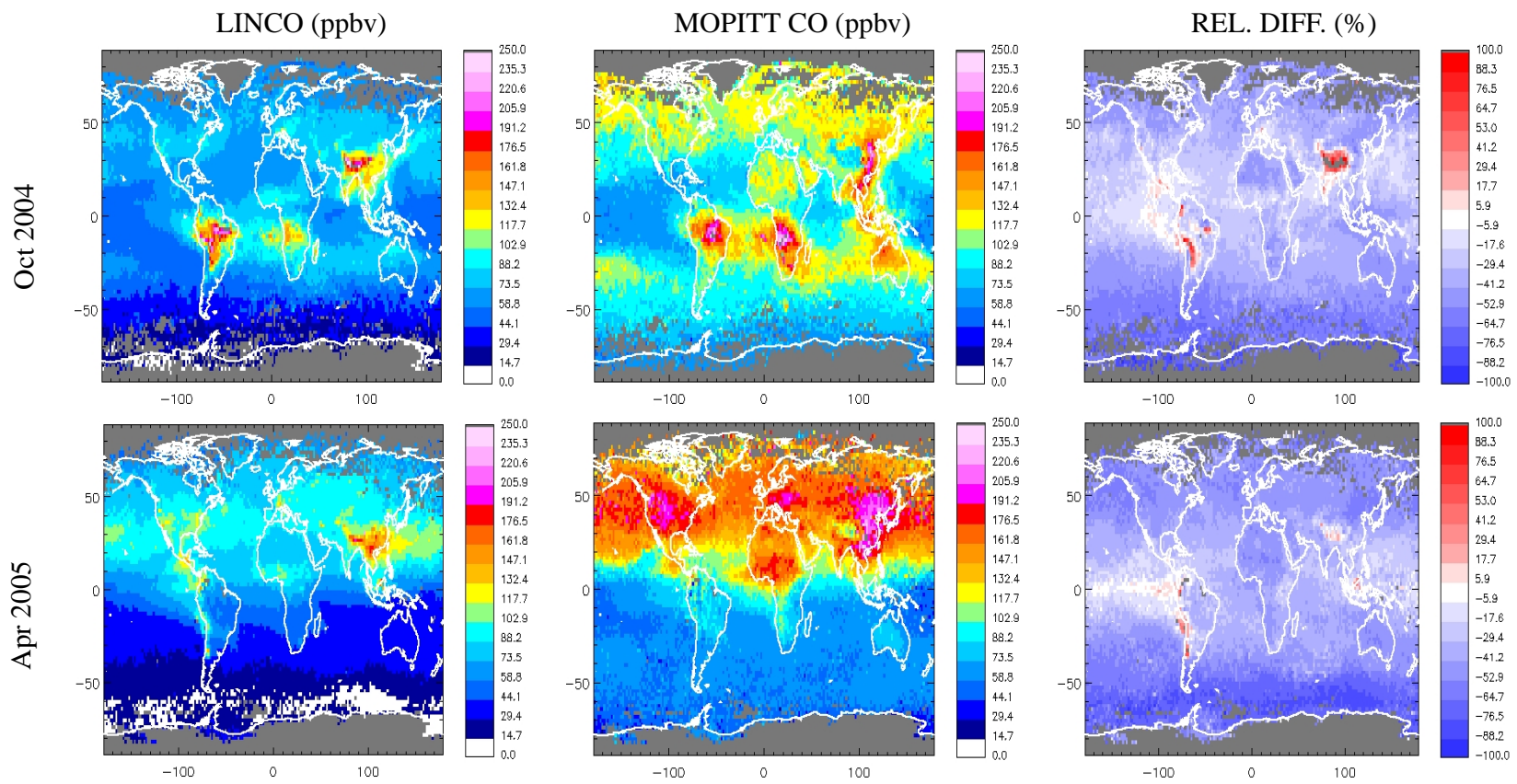

Fig. 5. CO fields in parts per billion by volume (ppbv) at $700 \mathrm{hPa}$ calculated by LINCO smoothed by MOPITT averaging kernels (left), MOPITT CO (ppbv) (middle) and corresponding relative differences (\%) (Model-Obs)/Obs x100 in October 2004 (upper panels) and April 2005 (lower panels).
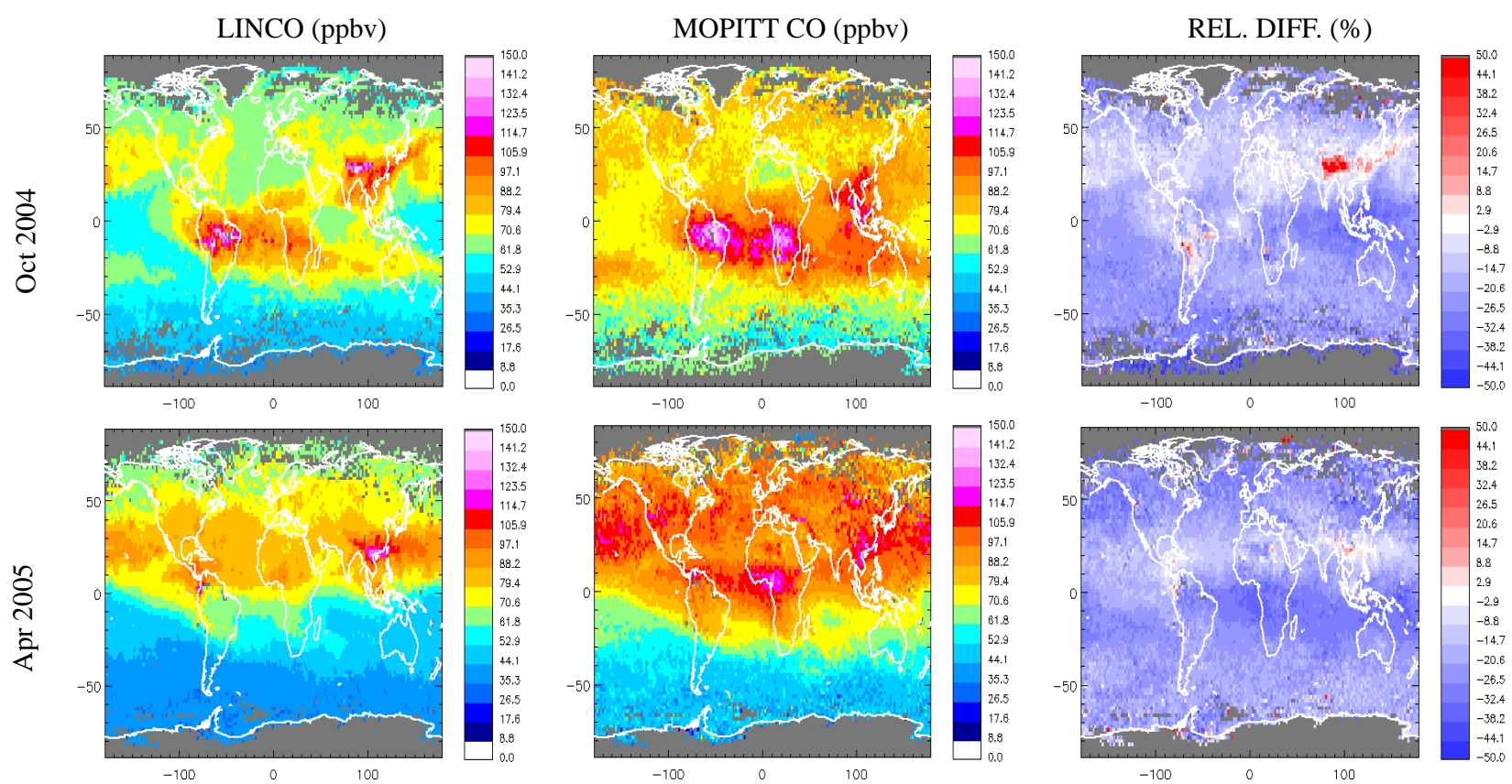

Fig. 6. Same as Fig. 5 but for $250 \mathrm{hPa}$.

This latter point is highlighted by Figs. 5 and 6 which present a comparison, for the specific months of October 2004 and April 2005, between results from LINCO and MOPITT CO retrievals at 700 and $250 \mathrm{hPa}$, respectively.
MOPITT CO at $700 \mathrm{hPa}$ (Fig. 5) shows generally high concentrations linked to intense emissions in the $\mathrm{NH}$ but also in regions of SH mostly affected by biomass burning such as South America, South Africa or Australia in October 2004. 

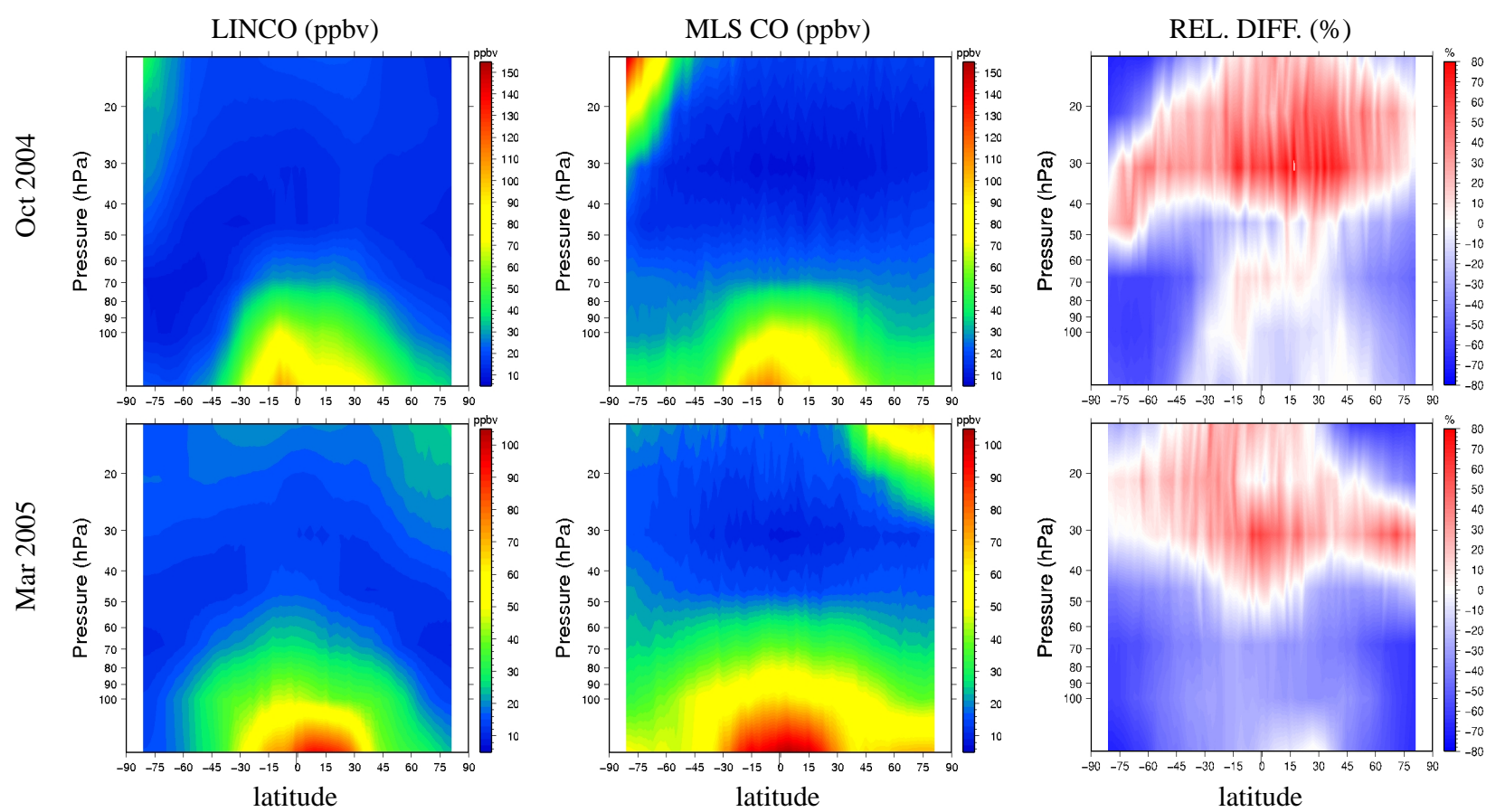

Fig. 7. Zonal monthly mean of CO from LINCO (left) and MLS (middle) in parts per billion by volume (ppbv) and corresponding relative differences (\%) (right) for October 2004 (upper panel) and March 2005 (lower panel). Pressure levels are selected from 146 to 14 hPa. Note that LINCO mixing ratios have been smoothed by triangular MLS averaging kernels.

LINCO also underestimates the CO retrieved from MOPITT measurements in April 2005 reinforcing the idea of too much destruction of $\mathrm{CO}$ in the linear scheme combined with too low emissions used in CTMs as suggested by Shindell et al. (2006) or lately by Pison et al. (2009).

Nevertheless, LINCO tends to accumulate CO over the Tibetan plateau especially in October 2004 (Fig. 5), which is located near populated regions with high emissions. Li et al. (2005) suggested that the boundary layer pollution, transported by Asian summer monsoon convection, is trapped by the Tibetan anticyclone. The model appears to overestimate this accumulation compared to MOPITT data. A similar behaviour is observed over the Tibetan plateau using RACMOBUS which confirms that this overestimation is not linked to the LINCO chemistry but rather to transport and dynamics (common to the two simulations). In Fig. 6, similar remarks as in Fig. 5 can be made, but a smaller bias is noticed between LINCO and MOPITT CO concentrations, $\sim-20 \%$ instead of $\sim-40 \%$ at $750 \mathrm{hPa}$.

\subsection{Comparison with satellite data in the stratosphere}

In this section, we compare the LINCO simulation with MLS $\mathrm{CO}$ data, in order to evaluate the CO linear scheme in the lower stratosphere. CO fields from LINCO simulation are smoothed by a theoretical triangular averaging kernel with the full-width at half-maximum equal to the MLS vertical resolution according to Pumphrey et al. (2007). This is made to represent the contribution of the range of layers of the atmosphere for which the satellite retrieval is sensitive. This contribution is important in the lower stratosphere where $\mathrm{CO}$ vertical gradients are strong. Figure 7 presents the $\mathrm{CO}$ monthly zonal means for the month of October 2004 and March 2005 calculated for LINCO and MLS CO. The MLS pressure levels are selected from 146 to $14 \mathrm{hPa}$. For both months, the vertical and latitudinal gradients of $\mathrm{CO}$ in the UTLS for pressures larger than $70 \mathrm{hPa}$ are well represented by the model compared to MLS CO with the same range of mixing ratios except over the poles, where the LINCO mixing ratios are underestimated compared to the $\mathrm{CO}$ observed by MLS. This may be explained by a too rapid transport of the meridional circulation observed in ARPEGE analysis used in this study. This behaviour has already been reported by (e.g., van Noije et al., 2004; Monge-Sanz et al., 2006) for ECMWF reanalyses. In the same way, Teyssèdre et al. (2007) present similar behaviour with MOCAGE (using other years of ARPEGE analyses) and show that the age of the air is too young which suggest also a too rapid meridional transport. The mid-stratospheric air, where CO is less concentrated, is transported downward into the lower stratosphere too fast. It leads to smaller CO concentrations than the ones actually found by MLS in the lower stratosphere.

Above the altitude pressure of $20 \mathrm{hPa}$, an increase of CO is observed by MLS both for the South pole in October 2004 and for the North pole in March 2005. Jin et al. (2009) 

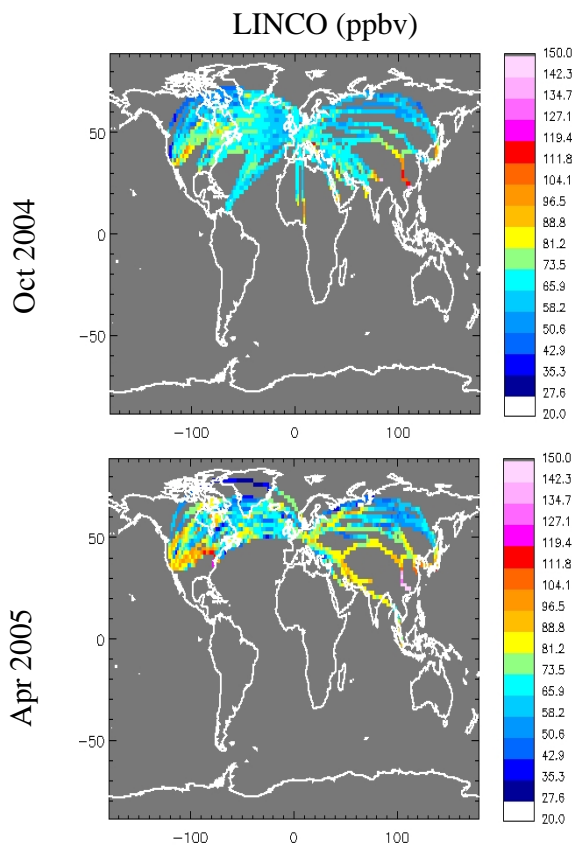
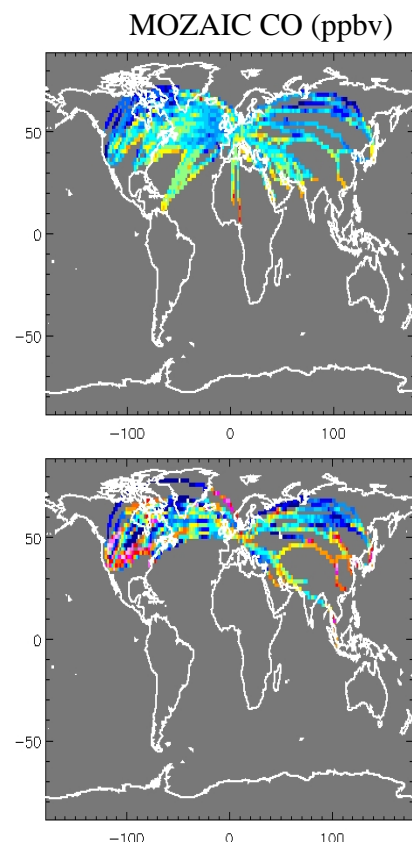
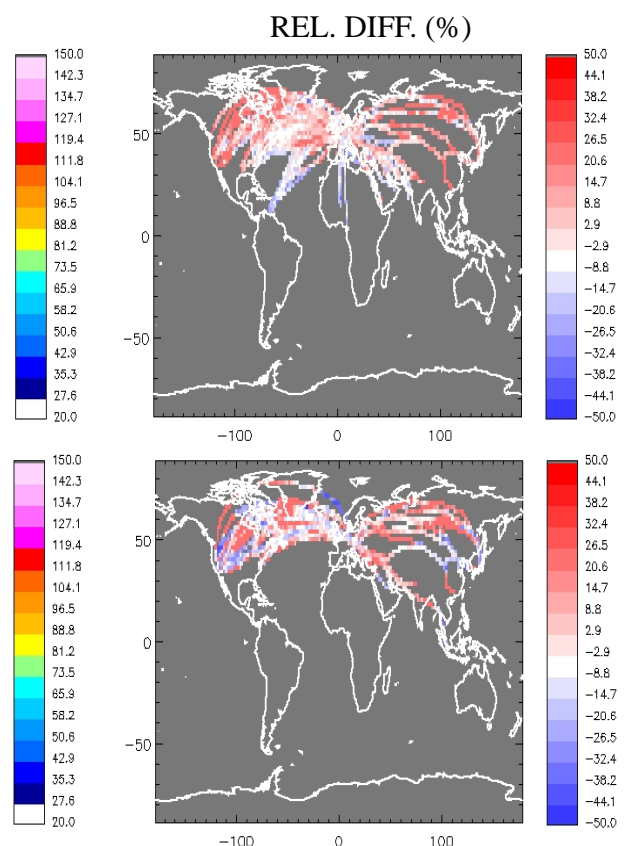

Fig. 8. CO fields from LINCO (left) and measured by MOZAIC aircraft (center) in parts per billion by volume (ppbv) and corresponding relative differences (\%) (right) (Model-Obs)/Obs x100 in October 2004 (upper panel) and April 2005 (lower panel) for pressures between 300 and $180 \mathrm{hPa}$.

presents the mesospheric descent observed by MLS, ACEFTS (Atmospheric Chemistry Experiment Fourier Transform Spectrometer onboard SCISAT-1 satellite), Odin/SMR (SubMillimeter Radiometer onboard Odin satellite) and simulated by the Canadian Middle Atmosphere Model at higher altitudes for the same period. Compared to this study, the maximum of $\mathrm{CO}$ shown here above $20 \mathrm{hPa}$ only corresponds to the bottom part of the mesospheric descent. The values are underestimated by MOCAGE probably because of the model top, namely located at $5 \mathrm{hPa}$ and constrained by a zonal climatology. Consequently, MOCAGE leads to a misrepresentation of the mesospheric descent.

A positive bias is observed between MLS CO and LINCO for pressure levels between 45 and $10 \mathrm{hPa}$ for both months. As explained in Sect. 3.1, the bias may come from the LINCO coefficients $\left(A_{1}\right.$ and $\left.A_{3}\right)$ which relax to a CO climatology that is higher than measured by MLS at these stratospheric pressure levels.

\subsection{Comparison with MOZAIC aircraft data in the UTLS}

To evaluate the linear scheme in the UTLS region, we compared CO from MOZAIC aircraft data and model output interpolated on-line at flight times and locations. We averaged the observations where pressures are lower than $300 \mathrm{hPa}$ into boxes of $2^{\circ} \times 2^{\circ}$ in order to match the model resolution. In Fig. 8, the LINCO and the MOZAIC data are compared for the months of October 2004 and April 2005 which cor- respond to $\mathrm{CO}$ maxima in the $\mathrm{SH}$ and in the $\mathrm{NH}$, respectively. In both cases, LINCO tends to overestimate the aircraft observations, with very low biases, less than $2 \%$, but with a large standard deviation of $\sim 27 \%$. This indicates that LINCO does not present a systematic bias at the levels between $300 \mathrm{hPa}$ and $180 \mathrm{hPa}$. However, as expected, LINCO is not able to represent the variability observed by aircraft in situ measurements. In October 2004, the model represents well the spatial distribution of $\mathrm{CO}$ as observed by MOZAIC. Both observations and model show a meridional gradient between equator and high latitudes as aircraft fly in the lower stratosphere at mid-latitudes (low CO amounts of $\sim 50 \mathrm{ppbv}$ ) and in the troposphere at low latitudes (high CO amounts of $\sim 80 \mathrm{ppbv}$ ). An overestimation of the LINCO concentration is observed over the Tibetan Plateau, where the model accumulates CO as described in Sect. 3.2. In April 2005, an increase of $\mathrm{CO}$ is observed by MOZAIC over polluted areas in the South-Center USA and over Asia. The model underestimates this increase of $\mathrm{CO}$ concentration in the higher troposphere as was concluded in Sect. 3.2 by comparison with MOPITT CO. 


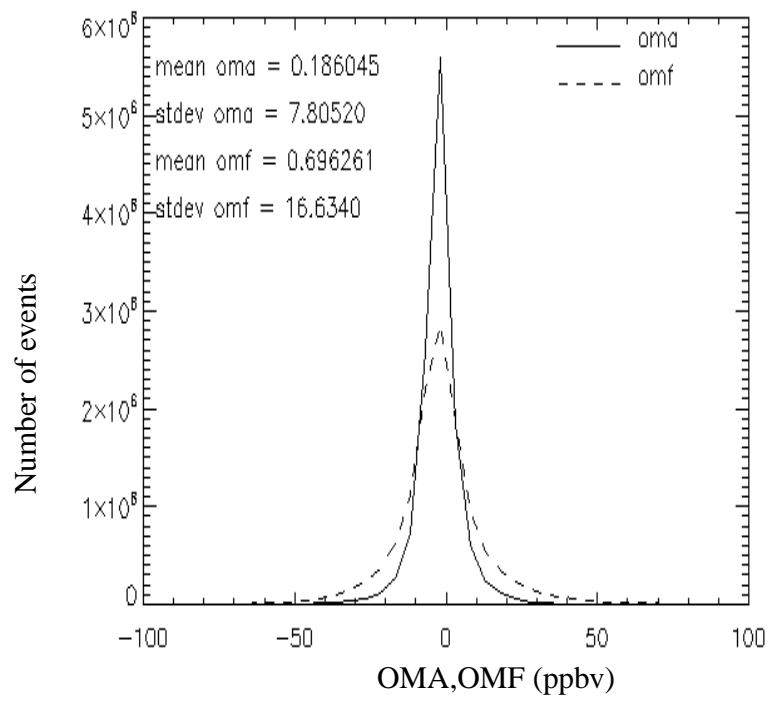

Fig. 9. Histograms of Observations Minus Analyses (OMA: solid lines) and Observations Minus Forecast (OMF: dashed lines) for the 7 MOPITT levels (surface, 850, 700, 500, 350, 250 and $150 \mathrm{hPa}$ ) and from July 2004 to July 2005.

\section{Evaluation of a one year of MOPITT CO data assimilation with the linear scheme}

\subsection{Assimilation diagnostics}

The linear scheme of $\mathrm{CO}$ is used here to demonstrate its great interest for data assimilation over long periods of time due to its low computational cost. The assimilation experiment started on 1 December 2003 and ended on 1 July 2005. The initial 3-D field of atmospheric constituents is the same as for twin runs for LINCO and RACMOBUS discussed in Sect. 3. MOPITT data are averaged in boxes of $2^{\circ} \times 2^{\circ}$ to obtain super-observations directly assimilated into the used version of the MOCAGE-PALM system. Moreover, in order to take into account the vertical resolution of the MOPITT measurements, their averaging kernels as well as their a priori profiles are considered in the assimilation procedure. Note that the variance-covariance error matrices of MOPITT measurements are also taken into account during the assimilation process through the error covariance matrix of the observations. The analysed fields are studied for the period between July 2004 and July 2005. The period prior to 1 July 2004 is assumed to be perturbed by spinup effects, and thus is not considered in our analysis.

We check the consistency of the observations minus analyses (OMA) and observations minus forecast (OMF) in order to evaluate the quality of the $\mathrm{CO}$ assimilated fields. Figure 9 shows the two distributions of OMA and OMF for all of the 7 MOPITT levels and for the full period (July 2004July 2005). Both distributions are nearly Gaussian and therefore are assumed to have a Gaussian error. The mean of OMF
Table 1. Mean correlation bias and standard deviation in $\%$ between MOZAIC aircraft CO data set and the LINCO run and between the MOPITT CO assimilated fields at 700 (775-600), 500 (600-425) 350 ( 425-260) and $250(260-240) \mathrm{hPa}$.

\begin{tabular}{ccccc}
\hline & \multicolumn{2}{c}{ LINCO-MOZAIC } & \multicolumn{2}{c}{ MOPAN-MOZAIC } \\
\hline Pressure $(\mathrm{hPa})$ & Corr & Bias $\%$ & Corr & Bias \% \\
\hline 250 & 0.69 & $-0.1 \pm 26.8$ & 0.69 & $16.2 \pm 31.9$ \\
350 & 0.54 & $-8.8 \pm 23.3$ & 0.62 & $10.8 \pm 26.2$ \\
500 & 0.31 & $-21.0 \pm 17.2$ & 0.50 & $7.2 \pm 18.3$ \\
700 & 0.26 & $-25.5 \pm 25.8$ & 0.42 & $8.6 \pm 24.6$ \\
\hline
\end{tabular}

values is close to zero ( $\sim 0.7 \mathrm{ppbv})$ with a standard deviation of $\sim 16.6 \mathrm{ppbv}(\sim 21 \%)$, which indicates a small bias between MOPITT observations and model forecast. The standard deviation and the mean value of OMA (with a correlation coefficient of 0.99) are smaller than that of OMF (with a correlation coefficient of 0.94 ) which shows that the analyses are closer to the observations than the forecast. This again indicates that the assimilation system behaves properly.

\subsection{Evaluation of $\mathrm{CO}$ analyses}

\subsubsection{Comparison in the troposphere with independent MOZAIC aircraft data}

In this section, we use MOZAIC CO as independent data in order to evaluate MOPITT CO assimilated fields (hereinafter referred to MOPan) and the LINCO simulation (reference standard simulation) with the objective to determine the added-value of data assimilation. Table 1 presents correlation, bias and standard deviations between LINCO and MOZAIC CO, and between MOPan and MOZAIC CO. LINCO underestimates $\mathrm{CO}$ in the lower troposphere with a negative bias of $-25 \%$ compared to MOZAIC at $700 \mathrm{hPa}$ whereas MOPan reduces this bias to a positive value of $8.6 \%$. These results are consistent with the bias of $+5 \%$ obtained by Emmons et al. (2009) directly considering MOPITT and MOZAIC in 2004 over coincident profiles. In this study, we consider all MOZAIC profiles and not only MOPITT coincident profiles as done by Emmons et al. (2009) which may lead to a slightly different bias $(+8 \%$ instead of $+5 \%)$. As presented in Sect. 3.4, the model tends to increase the $\mathrm{CO}$ concentrations in the UTLS region. This may explain the differences between a $\sim 16 \%$ bias found between MOZAIC data and MOPan at $250 \mathrm{hPa}$ and a $\sim 2 \%$ bias between MOZAIC and MOPITT CO data found by Emmons et al. (2009) for the same period.

In order to go a step further in our analysis, $\mathrm{CO}$ averaged profiles are presented over 3 regions of the globe: North America (140-30 W, 15-70 N), Europe (20 W-40 E, $15-75 \mathrm{~N})$ and Asia $(60-160 \mathrm{E}, 5-50 \mathrm{~N})$ and for the different seasons: NH summer, autumn, winter and spring 2004-2005. 

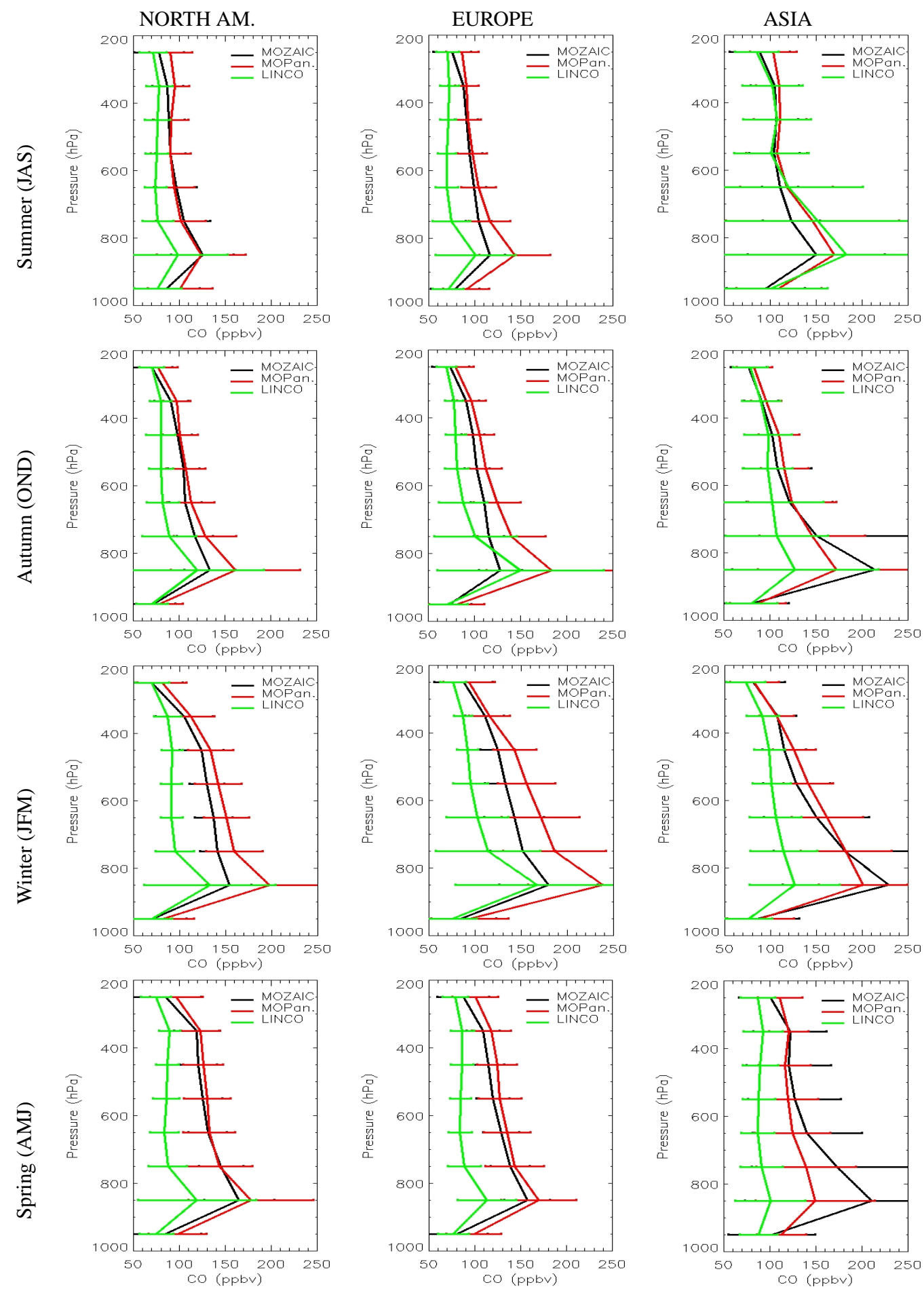

Fig. 10. Mean profiles of CO in parts per billion by volume (ppbv) from LINCO (green lines), MOZAIC (black lines) and MOPITT CO assimilated fields (red lines) in 2004-2005 NH summer July-August-September (JAS) autumn October-November-December (OND) winter January-February-March (JFM) and spring April-May-June (AMJ) over North America (right), Europe (center) and Asia (right).

In Fig. 10, MOZAIC CO profiles are plotted on 8 isobars at $950,850,750,650,550,450,350$ and $250 \mathrm{hPa}$, averaged within the 8 layers: surface- $900 \mathrm{hPa}, 900-800 \mathrm{hPa}, 800$ $700 \mathrm{hPa}, 700-600 \mathrm{hPa}, 600-500 \mathrm{hPa}, 500-400 \mathrm{hPa}, 400$
$300 \mathrm{hPa}$ and 300-220 hPa respectively. For all cases, except over Asia during $\mathrm{NH}$ summer, LINCO underestimates the $\mathrm{CO}$ concentration compared to MOZAIC CO with a negative bias of $\sim 40 \mathrm{ppbv}$ at $850 \mathrm{hPa}$, decreasing with altitude 

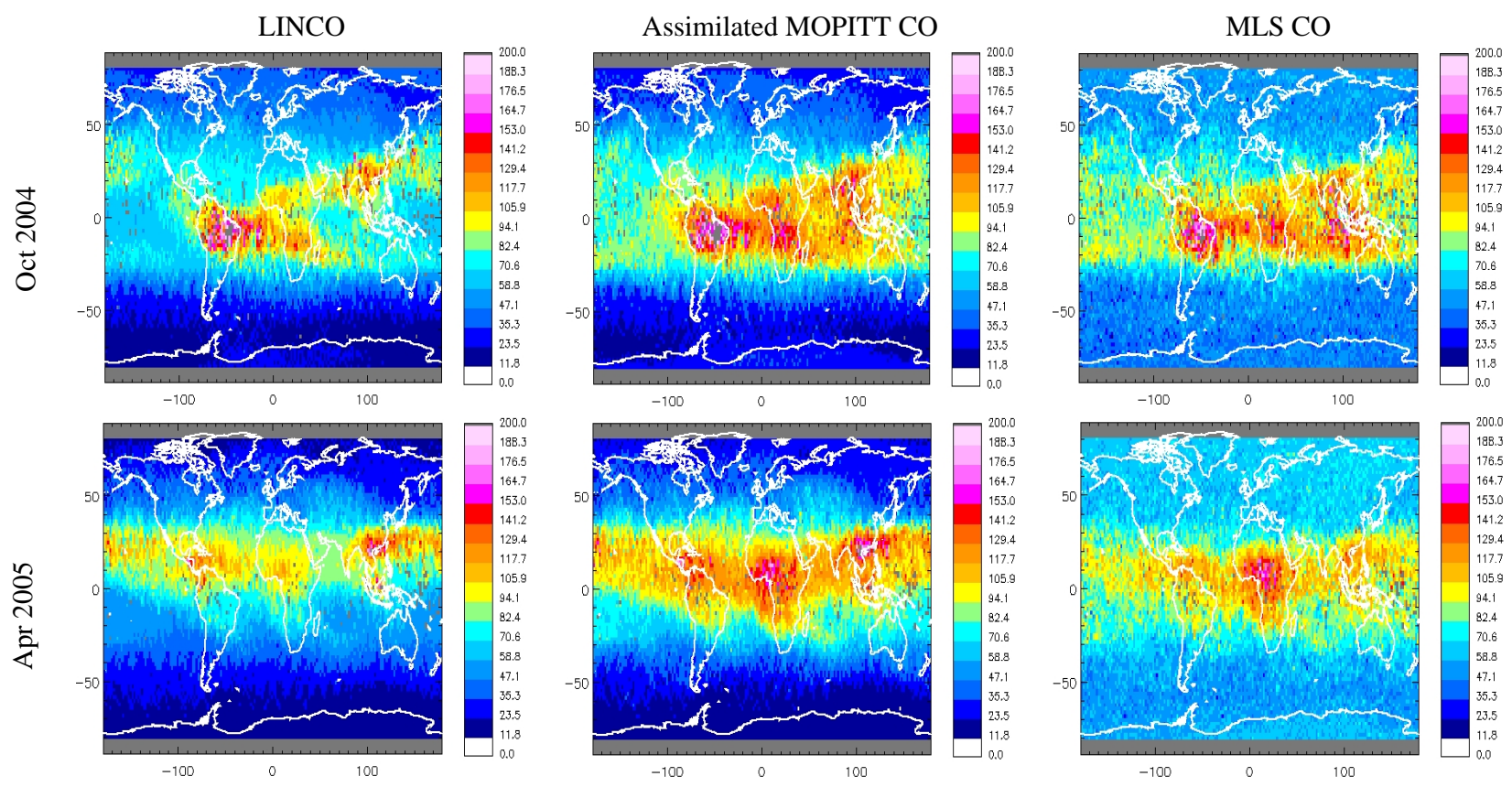

Fig. 11. CO fields calculated by LINCO (left), assimilated MOPITT CO (center) and MLS CO (right) in parts per billion by volume (ppbv) in October 2004 (upper panel) and April 2005 (lower panel) at $146 \mathrm{hPa}$. Note that LINCO and assimilated MOPITT CO have been smoothed by triangular MLS averaging kernels.

until $250 \mathrm{hPa}$ where the negative bias is low ( $\sim 10 \mathrm{ppbv}$, $\sim 13 \%$ ). The assimilation of MOPITT CO data improves greatly the vertical distribution of $\mathrm{CO}$ which shows MOPan profiles closer to the MOZAIC independent data than free run LINCO for pressures between 750 to $350 \mathrm{hPa}$. However, compared to MOZAIC, MOPan overestimates $\mathrm{CO}$ at $850 \mathrm{hPa}$ in October-November-December 2004 and JanuaryFebruary-March 2005 over Europe and North America. Nevertheless, $850 \mathrm{hPa}$ is likely not the most MOPITT reliable level for MOPITT data according to Emmons et al. (2004). In the lower troposphere and over Asia, LINCO slightly overestimates $\mathrm{CO}$ in summer (July-August-September) but widely underestimates $\mathrm{CO}$ during the other seasons. This is likely due to a mis-specified fossil fuel burning in the inventory emissions of the model over Asia as suggested by Shindell et al. (2006). The data assimilation corrects this discrepancy by decreasing the $\mathrm{CO}$ concentration in summer and increasing $\mathrm{CO}$ elsewhere. Moreover, the annual added $\mathrm{CO}$ mass in the troposphere by the MOPITT CO assimilation (via the assimilation increment) is estimated to be $680 \mathrm{Tg}$. This corresponds to $\sim 68 \%$ of the total mass introduced during one year by the emission inventory.

\subsubsection{Comparison in the UTLS with MLS}

MOZAIC data are only available up to $190 \mathrm{hPa}$, therefore we used independent MLS data at $147 \mathrm{hPa}$ which is nearly an overlapped level with MOPITT at $150 \mathrm{hPa}$ to evaluate MOPan at higher altitude. We applied the same theoreti- cal triangular averaging kernel as described in Sect. 3.3. In Fig. 11, we compare MLS CO to LINCO and MOPan simulated CO interpolated at MLS locations at $146 \mathrm{hPa}$. For October 2004, the results calculated with LINCO are different from the corresponding MLS CO fields. Over South America, CO fields from LINCO are quite similar to MLS observations. Conversely, over Africa, there is an underestimation of the CO concentration compared to MLS data likely inducing the stronger underestimation over South East Asia due to horizontal and vertical transport deficiencies and also to too much $\mathrm{CO}$ destruction and too low emissions over Africa in the linear scheme. In the same way, for April 2005, the same behavior is observed as for October 2004, with strong underestimation of $\mathrm{CO}$ mainly over Africa. For both months, MOPITT CO data assimilation corrects these underestimates by increasing the CO concentration over Africa and South East Asia. MOPan improves the quality of the CO distribution compared to MLS into the tropics by reducing the bias between the model and the observations from $-15 \%$ without assimilation to $5 \%$ and increasing the correlation from 0.65 without assimilation to 0.75 with assimilation. At extratropical latitudes the bias between MLS and MOPan is higher $(-50 \%)$ because MOPITT data are more scattered and therefore the low model values due to the too rapid meridional circulation (as described in Sect. 3.3) are predominant. Moreover the MLS data are assumed to have an uncertainty of $\pm 30 \%$ according to Livesey et al. (2008), which may also contribute to this high difference between MOPITT CO analyses and MLS CO at high latitudes. 


\section{Summary and conclusions}

In this study, we have presented a new linear parameterization for CO (LINCO) which can be used both in the troposphere and in the stratosphere. In order to evaluate this linear chemical scheme, we have implemented the parameterization into the MOCAGE CTM. In a first part, the results of LINCO have been compared to the detailed chemical scheme of MOCAGE, RACMOBUS. LINCO results have also been compared to several CO measurements from satellite instruments (MOPITT in the troposphere and MLS in the stratosphere) and from in situ aircraft data (MOZAIC) in the UTLS. In a second part, we have assimilated MOPITT $\mathrm{CO}$ with LINCO over one and a half years and compared analyses to independent observations (MOZAIC and MLS) to evaluate the quality of the results. This evaluation was done to demonstrate the interest of the LINCO low computation cost which allows data assimilation over long periods of time.

The CO distributions of both the linear and the detailed chemical schemes behave qualitatively similarly. The linear scheme has smaller $\mathrm{CO}$ concentrations in the troposphere and larger $\mathrm{CO}$ concentrations in the stratosphere compared to RACMOBUS. We deduced that these differences are mainly due in the troposphere to a too high destruction of $\mathrm{CO}$ concentration by the production minus loss rate LINCO coefficient $\left(A_{1}\right)$. Indeed, the emission inventory used with LINCO in MOCAGE is different from the CO climatology at the surface used in MOBIDIC. This naturally leads to tropospheric biases in the LINCO scheme, because the $A_{1}$ coefficient remains fixed. In the stratosphere the positive bias between LINCO and RACMOBUS, is partly due to the positive bias between the $\mathrm{CO}$ climatological coefficient $\left(A_{3}\right)$ and RACMOBUS. However differences between the two chemical schemes remain quite small ( $\sim 30 \mathrm{ppbv}, 20 \%)$. The comparisons between model results and MOPITT CO data globally show a good agreement. The model is able to capture the main spatial patterns of $\mathrm{CO}$ and to represent the seasonal $\mathrm{CO}$ variations with a maximum in the $\mathrm{NH}$ in April and a maximum in the SH in October as observed in MOPITT data. A negative bias of LINCO in the troposphere is observed compared to MOPITT CO, predominant in the $\mathrm{NH}$ with a maximum near the surface (30-40 ppbv at $850 \mathrm{hPa}$ ) and a decrease with altitude $(20 \mathrm{ppbv}$ at $250 \mathrm{hPa})$. One can note that this negative bias is quite similar or a little higher to this encountered between LINCO and RACMOBUS. In the lower and middle stratosphere, LINCO simulates very well the $\mathrm{CO}$ concentrations distributions except at the poles where $\mathrm{CO}$ concentrations are underestimated. We suggest that this deficiency in LINCO is related to a too rapid downward transport of poor $\mathrm{CO}$ air from middle stratosphere to the lower stratosphere at the poles. In the UTLS, we obtained a very good agreement between LINCO results and MOZAIC CO observations with a small bias of $+2 \%$ but with a large variability of $\pm 27 \%$.
The MOPITT CO analyses generally show a good agreement with the MOZAIC observations and reduce the negative bias in the troposphere compared to the model without assimilation and MOZAIC (from $\sim-20 \%$ without assimilation to $\sim+8 \%$ with assimilation). At $250 \mathrm{hPa}$, the bias between MOPITT CO analyses and MOZAIC is larger than the bias between MOPITT CO and MOZAIC CO obtained by Emmons et al. (2009) likely because of the model transport deficiency. We compared MOZAIC CO profiles with LINCO profiles over North America, Europe and Asia for different seasons. In each case, the assimilation greatly improves the $\mathrm{CO}$ vertical distribution from 700 to $350 \mathrm{hPa}$. The annual added $\mathrm{CO}$ mass in the troposphere by the MOPITT $\mathrm{CO}$ assimilation is estimated to be $680 \mathrm{Tg}$, which corresponds to $\sim 68 \%$ of the total mass introduced by the emission inventory during one year. MOPITT CO analyses also present a good agreement with MLS data at $146 \mathrm{hPa}$. However, at extratropical latitudes, MOPITT CO analyses underestimate the $\mathrm{CO}$ concentration compared to MLS CO $(\sim-50 \%)$. This bias may be related to a too rapid downward transport of the meridional circulation.

Finally, we show that the linear parameterization for $\mathrm{CO}$, introduced in a CTM, is able to represent reasonably well the main $\mathrm{CO}$ distribution in the troposphere and the lower stratosphere. In the context of data assimilation, we have shown that the bias is corrected by using MOPITT CO observations. The main advantage of such a chemical scheme is its low computing cost (only one tracer) which makes possible simulation and data assimilation for long periods. It is now possible to assimilate data at higher global resolution (for example $0.5^{\circ}$ instead of $2^{\circ}$ actually used) to use the full horizontal resolution of current nadir satellite-borne instruments.

Acknowledgements. This work was funded by the Centre National de Recherches Scientifiques (CNRS), Astrium-EADS and the Centre National de Recherches Météorologiques (CNRM) of Météo-France. The authors acknowledge for the strong support of the European Commission, Airbus, and the Airlines (Lufthansa, Austrian, Air France) who carry free of charge the MOZAIC equipment and perform the maintenance since 1994. MOZAIC is presently funded by INSU-CNRS (France), Météo-France and Forschungszentrum (FZJ, Julich, Germany). The MOZAIC data based is supported by ETHER (CNES and INSU-CNRS). Work at the Jet Propulsion Laboratory, California Institute of Technology, was done under contract with the National Aeronautics and Space Administration. ETHER (ADOMOCA programme) and the Région Midi-Pyrénées are also acknowledged.

Edited by: W. Lahoz 


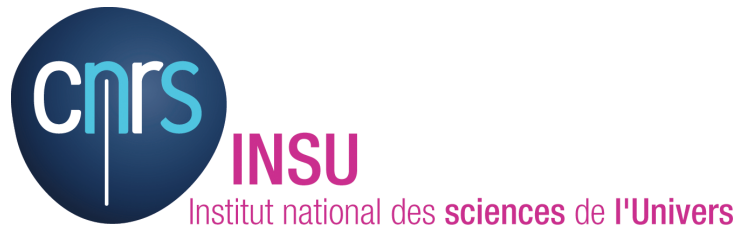

The publication of this article is financed by CNRS-INSU.

\section{References}

Andersson, E., Beljaars, A., Bidlot, J., Miller, M., Simmons, A., and Thepaut, J. N.: A major new cycle of the IFS: cycle 25R4, in: ECMWF Newsletter 97, ECMWF, Shinfield Park, Reading,Berkshire RG2, 9AX, UK, 2003.

Barret, B., Ricaud, P., Mari, C., Attié, J.-L., Bousserez, N., Josse, B., Le Flochmoën, E., Livesey, N. J., Massart, S., Peuch, V.H., Piacentini, A., Sauvage, B., Thouret, V., and Cammas, J.P.: Transport pathways of $\mathrm{CO}$ in the African upper troposphere during the monsoon season: a study based upon the assimilation of spaceborne observations, Atmos. Chem. Phys., 8, 3231-3246, doi:10.5194/acp-8-3231-2008, 2008.

Bechtold, P., Bazile, E., Guichard, F., Mascart, P., and Richard, E.: A mass-flux convection scheme for regional and global models, Q. J. Roy. Meteor. Soc., 127, 869-886, 2001.

Bousserez, N., Attié, J.-L., Peuch, V.-H., Michou, M., Pfister, G., Edwards, D., Emmons, L., Mari, C., Barret, B., Arnold, S. R., Heckel, A., Richter, A., Schlager, H., Lewis, A., Avery, M., Sachse, G., Browell, E. V., and Hair, J. W.: Evaluation of the MOCAGE chemistry transport model during the ICARTT/ITOP experiment, J. Geophys. Res., 112, D10S42, doi: 10.1029/2006JD007595, 2007.

Buis, S., Piacentini, A., and Déclat, D.: PALM: a computational framework for assembling high-performance computing applications, Concurrency Computat.: Pract. Exper., 18, 231-245, 2006.

Cammas, J.-P. and Volz-Thomas, A.: The MOZAIC program (1994-2007), International Global Atmospheric Chemistry (IGAC) Newsletter, 37, November 2007, 2007.

Cariolle, D. and Déqué, M.: Southern hemisphere medium-scale waves and total ozone disturbances in a spectral general circulation model, J. Geophys. Res., 91, 10825-10846, 1986.

Cariolle, D., Evans, M. J., Chipperfield, M. P., Butkovskaya, N., Kukui, A., and Le Bras, G.: Impact of the new $\mathrm{HNO}_{3}$ forming channel of the $\mathrm{HO}_{2}+\mathrm{NO}$ reaction on tropospheric $\mathrm{HNO}_{3}, \mathrm{NO}_{\mathrm{x}}, \mathrm{HO}_{\mathrm{x}}$ and ozone, Atmos. Chem. Phys., 8, 40614068, doi:10.5194/acp-8-4061-2008, 2008.

Cariolle, D. and Teyssèdre, H.: A revised linear ozone photochemistry parameterization for use in transport and general circulation models: multi-annual simulations, Atmos. Chem. Phys., 7, 2183-2196, doi:10.5194/acp-7-2183-2007, 2007.

Cathala, M. L., Pailleux, J., and Peuch, V.-H.: Improving chemical simulations of the upper troposphere-lower stratosphere with sequential assimilation of MOZAIC data, Tellus, 55B, 1-10, 2003.

Clark, H. L., Cathala, M.-L., Teyssèssdre, H., Cammas, J.-P., and Peuch, V.-H.: Cross-tropopause fluxes of ozone unsing assimilation of MOZAIC observations in a global CTM, Tellus, 59B, 39-49, 2007.

Courtier, P., Freydier, C., Geleyn, J., Rabier, F., and Rochas, M.: The ARPEGE project at Météo France, in: Atmospheric Models,
2, 193-231, Workshop on Numerical Methods, Reading, UK, 1991.

Coy, L., Allen, D. R., Eckermann, S. D., McCormack, J. P., Stajner, I., and Hogan, T. F.: Effects of model chemistry and data biases on stratospheric ozone assimilation, Atmos. Chem. Phys., 7, 2917-2935, doi:10.5194/acp-7-2917-2007, 2007.

Deeter, M., Emmons, L., Francis, G., Edwards, D., Gille, J., Warner, J., Khattatov, B., Ziskin, D., Lamarque, J., SP, S. H., Yudin, V., Attié, J.-L., Packman, D., Chen, J., Mao, D., and Drummond, J.: Operational carbon monoxide retrieval algorithm and selected results for the MOPITT instrument, J. Geophys. Res., 108, 4339, doi:10.1029/2002JD003186, 2003.

Dentener, F., Stevenson, D., Cofala, J., Mechler, R., Amann, M., Bergamaschi, P., Raes, F., and Derwent, R.: The impact of air pollutant and methane emission controls on tropospheric ozone and radiative forcing: CTM calculations for the period 19902030, Atmos. Chem. Phys., 5, 1731-1755, doi:10.5194/acp-51731-2005, 2005.

Déqué, M., Dreveton, C., Braun, A., and Cariolle, D.: The ARPEGE/IFS atmosphere model: a contribution to the French community climate modelling, Clim. Dynam., 10, 249-266, 1994.

Drummond, J. R. and Mand, G. S.: Evaluation of operational radiances for the Measurement of Pollution in the Troposphere (MOPITT) instrument CO thermal-band channels, J. Geophys. Res., 109, D03308, doi:10.1029/2003JD003970, 1996.

Dufour, A., Amodei, M., Ancellet, G., and Peuch, V.-H.: Observed and modelled "chemical weather" during ESCOMPTE, Atmos. Res., 74, 161-189, 2004.

Edwards, D. P., Lamarque, J.-F., Attié, J.-L., Emmons, L. K., Richter, A., Cammas, J.-P., Gille, J. C., Francis, G. L., Deeter, M. N., Warner, J., Ziskin, D. C., Lyjak, L. V., Drummond, J. R., and Burrows, J. P.: Tropospheric ozone over the tropical Atlantic: A satellite perspective, J. Geophys. Res., 108, D84237, doi:10.1029/2002JD002927, 2003.

Edwards, D. P., Petron, G., Novelli, P. C., Emmons, L. K., Gille, J. C., and Drummond, J. R.: Southern Hemisphere carbon monoxide interannual variability observed by Terra/Measurement of Pollution in the Troposphere (MOPITT), J. Geophys. Res., 111, D16303, doi:10.1029/2006JD007079, 2006.

El Amraoui, L., Attié, J.-L., Semane, N., Claeyman, M., Peuch, V.H., Warner, J., Ricaud, P., Cammas, J.-P., Piacentini, A., Josse, B., Cariolle, D., Massart, S., and Bencherif, H.: Midlatitude stratosphere - troposphere exchange as diagnosed by MLS $\mathrm{O}_{3}$ and MOPITT CO assimilated fields, Atmos. Chem. Phys., 10, 2175-2194, doi:10.5194/acp-10-2175-2010, 2010.

El Amraoui, L., Peuch, V.-H., Ricaud, P., Massart, S., Semane, N., Teyssèdre, H., Cariolle, D., and Karcher, F.: Ozone loss in the 2002-2003 Arctic vortex deduced from the assimilation of Odin/SMR O3 and N2O measurements: N2O as a dynamical tracer, Q. J. Roy. Meteor. Soc., 134, 217-228, 2008a.

El Amraoui, L., Ricaud, P., Urban, J., Théodore, B., Hauchecorne, A., Lautié, N., de La Noë, J., Guirlet, M., Flochmën, E. L., Murtagh, D., Dupuy, E., Frisk, U., and dÁndon, O.: Assimilation of Odin/SMR $\mathrm{O}_{3}$ and $\mathrm{N}_{2} \mathrm{O}$ measurements in a three-dimensional chemistry transport model, J. Geophys. Res., 109, D22304, doi: 10.1029/2004JD004796, 2004.

El Amraoui, L., Semane, N., Peuch, V.-H., and Santee, L.: Inves- 
tigation of dynamical processes in the polar stratospheric vortex during the unusually cold winter 2004/2005, Geophys. Res. Lett., 35, L03803, doi:10.1029/2007GL031251, 2008b.

Emmons, L., Deeter, M., Gille, J., Edwards, D., Attié, J.-L., Warner, J., Ziskin, D., Francis, G., Khattatov, B., Lamarque, V. Y. J.-F., Ho, S., Mao, D., Chen, J., Drummond, J., Novelli, P., Sachse, G., Coffey, M., Hannigan, J., Gerbig, C., Kawakami, S., Kondo, Y., Takegawa, N., Schlager, H., Baehr, J., and Ziereis, H.: Validation of Measurements of Pollution in the Troposphere (MOPITT) CO retrievals with aircraft in situ profiles, J. Geophys. Res., 109, D03309, doi:10.1029/2003JD004101, 2004.

Emmons, L. K., Edwards, D. P., Deeter, M. N., Gille, J. C., Campos, T., Ndlec, P., Novelli, P., and Sachse, G.: Measurements of Pollution In The Troposphere (MOPITT) validation through 2006, Atmos. Chem. Phys., 9, 1795-1803, doi:10.5194/acp-91795-2009, 2009.

Fisher, M. and Andersson, E.: Developments in 4D-Var and Kalman filtering, in: Technical Memorandum Research Department, 347, ECMWF, Reading, UK, 2001.

Freitas, S., Longo, K., Dias, M. S., Dias, P. S., Chatfield, R., Prins, E., Axtaxo, P., and Recuero, F.: Monitoring the transport of bimoass burning emissions in South America, Environ. Fluid. Mech., 5, 135-167, doi:10.1007/s1065200502437, 2005.

Giorgi, F. and Chameides, W.: Rainout lifetimes of highly soluble aerosols and gases as inferred from simulations with a general circulation model, J. Geophys. Res., 91(D13), 14367-14376, 1986.

Geer, A. J., Lahoz, W. A., Bekki, S., Bormann, N., Errera, Q., Eskes, H. J., Fonteyn, D., Jackson, D. R., Juckes, M. N., Massart, S., Peuch, V.-H., Rharmili, S., and Segers, A.: The ASSET intercomparison of ozone analyses: method and first results, Atmos. Chem. Phys., 6, 5445-5474, doi:10.5194/acp-6-5445-2006, 2006.

Geer, A. J., Lahoz, W. A., Jackson, D. R., Cariolle, D., and McCormack, J. P.: Evaluation of linear ozone photochemistry parametrizations in a stratosphere-troposphere data assimilation system, Atmos. Chem. Phys., 7, 939-959, doi:10.5194/acp-7939-2007, 2007.

Guan, H., Chatfield, R. B., Freitas, S. R., Bergstrom, R. W., and Longo, K. M.: Modeling the effect of plume-rise on the transport of carbon monoxide over Africa with NCAR CAM, Atmos. Chem. Phys., 8, 6801-6812, doi:10.5194/acp-8-6801-2008, 2008.

Hadjinicolaou, P., Pyle, J. A., and Harris, N. R. P.: The recent turnaround in stratospheric ozone over northern middle latitudes: A dynamical modeling perspective, Geophys. Res. Lett., 32, L12821, doi:10.1029/2005GL022476, 2005.

Jin, J. J., Semeniuk, K., Beagley, S. R., Fomichev, V. I., Jonsson, A. I., McConnell, J. C., Urban, J., Murtagh, D., Manney, G. L., Boone, C. D., Bernath, P. F., Walker, K. A., Barret, B., Ricaud, P., and Dupuy, E.: Comparison of CMAM simulations of carbon monoxide $(\mathrm{CO})$, nitrous oxide $\left(\mathrm{N}_{2} \mathrm{O}\right)$, and methane $\left(\mathrm{CH}_{4}\right)$ with observations from Odin/SMR, ACE-FTS, and Aura/MLS, Atmos. Chem. Phys., 9, 3233-3252, doi:10.5194/acp-9-3233-2009, 2009.

Josse, B., Simon, P., and Peuch, V.-H.: Radon global simulationwith the multiscale chemistry trasnport model MOCAGE, Tellus, 56, 339-356, 2004.

Lahoz, W. A., Errera, Q., Swinbank, R., and Fonteyn, D.: Data as- similation of stratospheric constituents: a review, Atmos. Chem. Phys., 7, 5745-5773, doi:10.5194/acp-7-5745-2007, 2007.

Lefèvre, F., Brasseur, G., Folkins, I., Smith, A., and Simon, P.: Chemistry of the 1991-1992 stratospheric winter: three dimensional model simulations, J. Geophys. Res., 99, 8183-8195, 1994.

Li, Q., Jiang, J., Wu, D., Read, W., Livesey, N., Waters, J., Zhang, Y., Wang, B., Filipiak, M., Davis, C., Turquety, S., Wu, S., Park, R., Yantosca, R. M., and Jacob, D.: Convective outflow of South Asian pollution: A global CTM simulation compared with EOS MLS observations, Geophys. Res. Lett., 32, L14826, doi:10.1029/2005GL022762, 2005.

Livesey, N., Filipiak, M., Froidevaux, L., Read, W., Lamber, A., Santee, M., Jiang, J., Pumphrey, H., Waters, J., Cofield, R., Cuddy, D., ad B.J. Drouin, W. D., Fuller, R., Jarnot, R., Jiang, Y., Ksnop, B., Li, Q., Perun, V., Schwartz, M., Snyder, W., Stek, P., Thurstans, R., Wagner, P., M.Avery, Browell, E., Cammas, J.-P., Christensen, L., G.S.Diskin, Gao, R.-S., Jost, H.-J., Loewenstein, M., Lopez, J., P.Nedelec, Osterman, G., G.W.Sachse, and Webster, C.: Validation of Aura Microwave Limb Sounder $\mathrm{O}_{3}$ and CO observations in the upper troposphere and lower stratosphere, J. Geophys. Res., 113, D15S02, doi:10.1029/2008JD008805, 2008.

Livesey, N., Read, W., Lambert, A., Cofield, R., Cuddy, D., Froidevaux, L., Fuller, R., Jarnot, R., Jiang, J., Jiang, Y., Knosp, B., Kovalenko, L., Pickett, H., Pumphrey, H., Santee, M., Schwartz, M., Stek, P., Wagner, P., Waters, J., and Wu, D.: EOS MLS version 2.2 Level 2 data quality and description document, Tech. Rep. JPL D-33509, Jet Propul. Lab., Pasadena, Calif., 2007.

Louis, J.-F.: Parametric model of vertical eddy fluxes in the atmosphere, Boundary Layer Meteorol., 17, 187-202, 1979.

McCormack, J. P., Eckermann, S. D., Coy, L., Allen, D. R., Kim, Y.J., Hogan, T., Lawrence, B., Stephens, A., Browell, E. V., Burris, J., McGee, T., and Trepte, C. R.: NOGAPS-ALPHA model simulations of stratospheric ozone during the SOLVE2 campaign, Atmos. Chem. Phys., 4, 2401-2423, doi:10.5194/acp-4-24012004, 2004.

McCormack, J. P., Eckermann, S. D., Siskind, D. E., and McGee, T. J.: CHEM2-D-OPP: A new linearized gas-phase ozone photochemistry parameterization for high-altitude NWP and climate models, Atmos. Chem. Phys., 6, 4943-4972, doi:10.5194/acp-64943-2006, 2006.

McLinden, C., Olsen, S., Hannegan, B., WIld, O., Prather, M., and Sundet, J.: Stratospheric ozone in 3-D models: A simple chemistry and the corss-tropopause flux, J. Geophys. Res., 105, 14653-14665, 2000.

Mari, C., Jacob, D. J., and Bechtold, P.: Transport and scavenging of soluble gases in a deep convective cloud, J. Geophys. Res., 105(D17), 22255-22267, 2000.

Marenco, A., Thouret, V., Nédélec, P., Smit, H., Helten, M., Kley, D., Karcher, F., Simon, P., Law, K., Pyle, J., Poschmann, G., von Wrede, R., Hume, C., and Cook, T.: Measurement of ozone and water vapour by Airbus in-service aircraft: the MOZAIC airborne program, An overview, J. Geophys. Res., 103, 2563125642, 1998

Massart, S., Cariolle, D., and Peuch, V.-H.: Towards an improvement of the atmospheric ozone distribution and variability by assimilation of satellite data, C. R. Geosci., 337, 1305-1310, 2005. 
Massart, S., Clerbaux, C., Cariolle, D., Piacentini, A., Turquety, S., and Hadji-Lazaro, J.: First steps towards the assimilation of IASI ozone data into the MOCAGE-PALM system, Atmos. Chem. Phys., 9, 5073-5091, doi:10.5194/acp-9-5073-2009, 2009.

Massart, S., Piacentini, A., Cariolle, D., El Amraoui, L., and Semane, N.: Assessment of the quality of the ozone measurements from the Odin/SMR instrument using data assimilation, Can. J. Phys., 85, 1209-1223, 2007.

Michou, M., Laville, P., Serca, D., Fotiadi, A., Bouchou, P., and Peuch, V.-H.: Measured and modeled dry deposition velocities over the ESCOMPTE area, Atmos. Res., 47, 89-116, 2004.

Michou, M. and Peuch, V.-H.: Surface exchanges in the MOCAGE multiscale Chemistry and Transport Model, Water Res., 15, 173203, 2002.

Monge-Sanz, B. M., Chipperfield, M. P., Simmons, A. J., and Uppala, S. M.: Mean age of air and transport in a CTM: Comparison of different ECMWF analyses, Geophys. Res. Lett., 34, L04801, doi:10.1029/2006GL028515, 2006.

Nedelec, P., Cammas, J.-P., Thouret, V., Athier, G., Cousin, J.-M., Legrand, C., Abonnel, C., Lecoeur, F., Cayez, G., and Marizy, C.: An improved infrared carbon monoxide analyser for routine measurements aboard commercial Airbus aircraft: technical validation and first scientific results of the MOZAIC III programme, Atmos. Chem. Phys., 3, 1551-1564, doi:10.5194/acp-3-15512003, 2003.

Oikonomou, E. K. and O'Neill, A.: Evaluation of ozone and water vapor fields from the ECMWF reanalysis ERA40 during 1991-1999 in comparison with UARS satellite and MOZAIC aircraft observations, J. Geophys. Res., 111, D14409, doi:10.1029/ 2004JD005341, 2006.

Peuch, V.-H., Amodei, M., Barthet, T., Cathala, M. L., Michou, M., and Simon, P.: MOCAGE, MOdéle de Chimie Atmosphérique à Grande Echelle, in: Proceedings of Météo France: Workshop on atmospheric modelling, pp. 33-36, Toulouse, FRANCE, 1999.

Pickering, K., Thompson, A., Y., W., Tao, W., Namara, D., Kirchhof, J., Sachse, G., Bradshaw, J., Gregory, G., and Blaki, D.: Convective transport of biomass burning emissions over Brazil during TRACEA, J. Geophys. Res., 101, 23993-24012, 1996.

Pison, I., Bousquet, P., Chevallier, F., Szopa, S., and Hauglustaine, D.: Multi-species inversion of $\mathrm{CH}_{4}, \mathrm{CO}$ and $\mathrm{H}_{2}$ emissions from surface measurements, Atmos. Chem. Phys., 9, 5281-5297, doi:10.5194/acp-9-5281-2009, 2009.

Pradier, S., Attié, J.-L., Chong, M., Escobar, J., Peuch, V.-H., Lamarque, J.-F., Khattatov, B., and Edwards, D.: Evaluation of 2001 springtime CO transport over West Africa using MOPITT CO measurements assimilated in a global chemistry transport model, Tellus, 58B, 163-176, 2006.

Pumphrey, H. C., Cofield, R. E., Filipiak, M. J., and Livesey, N. J.: An all-sky survey at $230 \mathrm{GHz}$ by MLS on Aura, Adv. Space Res., 43(3), 342-348, 2009.

Pumphrey, H., Filipiak, M., Livesey, N., Schwartz, M., Boone, C., Walker, K., Bernath, P., Ricaud, P., Barret, B., Clerbaux, C., Jarnot, R., Manney, G., and Waters, J.: Validation of middleatmosphere carbon monoxide retrievals from the Microwave Limb Sounder on Aura, J. Geophys. Res., 112, D24S38, doi: 10.1029/2007JD008723, 2007.

Ricaud, P., Attié, J.-L., Teyssèdre, H., El Amraoui, L., Peuch, V.H., Matricardi, M., and Schluessel, P.: Equatorial total column of nitrous oxide as measured by IASI on MetOp-A: implica- tions for transport processes, Atmos. Chem. Phys., 9, 39473956, doi:10.5194/acp-9-3947-2009, 2009.

Rodgers, C.: Inverse Methods for Atmospheric Sounding: Theory and Practice, vol. 2 of Series on Atmospheric, Oceanic and Planetary Physics, World Scientific, 2000.

Semane, N., Peuch, V.-H., Amraoui, L. E., Bencherif, H., Massart, S., Cariolle, D., Attié, J.-L., and Abidab, R.: An observed and analysed stratospheric ozone intrusion over the high Canadian Arctic UTLS region during the summer of 2003, Q. J. Roy. Meteor. Soc., 133, 171-178, 2007.

Semane, N., Peuch, V.-H., Pradier, S., Desroziers, G., El Amraoui, L., Brousseau, P., Massart, S., Chapnik, B., and Peuch, A.: On the extraction of wind information from the assimilation of ozone profiles in MétéoFrance 4-D-Var operational NWP suite, Atmos. Chem. Phys., 9, 4855-4867, doi:10.5194/acp-9-4855-2009, 2009.

Shindell, D., Faluvegi, G., Stevenson, D., Krol, M., Emmons, L., Lamarque, J.-F., Petron, G., Dentener, F., Ellingsen, K., Schultz, M., Wild, O., Amann, M., Atherton, C., Bergmann, D., Bey, I., Butler, T., Cofala, J., Collins, W., Derwent, R., Doherty, R., Drevet, J., Eskes, H., Fiore, A., Gauss, M., Hauglustaine, D., Horowitz, L., Isaksen, I., Lawrence, M., Montanaro, V., Muller, J.-F., Pitari, G., Prather, M., Pyle, J., Rast, S., Rodriguez, J., Sanderson, M., Savage, N., Strahan, S., Sudo, K., Szopa, S., Unger, N., van Noije, T., and Zeng, G.: Multimodel simulations of carbon monoxide: Comparison with observations and projected near-future changes, J. Geophys. Res., 111, D19306, doi:10.1029/2006JD007100, 2006.

Sinha, P., Jaegle, L., Hobbs, P., and Liang, Q.: Transport of biomass burning emissions from Southern Africa, J. Geophys. Res., 106, D20204, doi:10.1029/2004JD005044, 2004.

Staudt, A., Jacob, D., Logan, J., Bachiochi, D., Krishnamurti, T., and Sachse, G.: Continental sources, transoceanic transport, and interhemispheric exchange of carbon monoxide over the Pacific, J. Geophys. Res., 106, 32571-32590, 2001.

Stevenson, D. S., Dentener, F. J., Schultz, M. G., Ellingsen, K., van Noije, T. P. C., Wild, O., Zeng, G., Amann, M., Atherton, C. S., Bell, N., Bergmann, D. J., Bey, I., Butler, T., Cofala, J., Collins, W. J., Derwent, R. G., Doherty, R. M., Drevet, J., Eskes, H. J., Fiore, A. M., Gauss, M., Hauglustaine, D. A., Horowitz, L. W., Isaksen, I. S. A., Krol, M. C., Lamarque, J.-F., Lawrence, M. G., Montanaro, V., ller, J.-F. M., Pitari, G., Prather, M. J., Pyle, J. A., Rast, S., Rodriguez, J. M., Sanderson, M. G., Savage, N. H., Shindell, D. T., Strahan, S. E., Sudo, K., and Szopa, S.: Multimodel ensemble simulations of present-day and near-future tropospheric ozone, J. Geophys. Res., 111, D08301, doi:10.1029/ 2005JD006338, 2006.

Stockwell, W., Kirchner, F., M. Khun, M., and Seefeld, S.: A new mechanism for regional atmospheric chemistry modelling, J. Geophys. Res., 102, 25847-25879, 1997.

Stohl, A., Eckhardt, S., Forster, C., James, P., and Spichtinger, N.: On the pathways and timescales of intercontinental air pollution transport, J. Geophys. Res., 107, 4684, doi:10.1026/ 2001JD001396, 2002.

Teyssèdre, H., Michou, M., Clark, H. L., Josse, B., Karcher, F., Olivié, D., Peuch, V.-H., Saint-Martin, D., Cariolle, D., Attié, J.-L., Nédélec, P., Ricaud, P., Thouret, V., van der A, R. J., VolzThomas, A., and Chéroux, F.: A new tropospheric and stratospheric Chemistry and Transport Model MOCAGE-Climat for 
multi-year studies: evaluation of the present-day climatology and sensitivity to surface processes, Atmos. Chem. Phys., 7, 58155860, doi:10.5194/acp-7-5815-2007, 2007.

Thompson, A.: The Oxidizing Capacity of the Earths Atmosphere: Probale Past and Future Changes, Science, 256, 1157-1165, 1992.

van Noije, T. P. C., Segers, A. J., and van Velthoven, P. F. J.: Implications of the enhanced Brewer-Dobson circulation in European Centre for Medium-Range Weather Forecasts reanalysis ERA40 for the stratosphere-troposphere exchange of ozone in global chemistry transport models, J. Geophys. Res., 109, D19308, doi: 0.1029/2004JD004586, 2004.
Waters, J., Froidevaux, L., Harwood, R., Jarnot, R., Pickett, H., Read, W., Siegel, P., Cofield, R., Filipiak, M., Flower, D., Holden, J., Lau, G., Livesey, N., Manney, G., Pumphrey, H., Santee, M., Wu, D., Cuddy, D., Lay, R., Loo, M., Perun, V., Schwartz, M., Stek, P., Thurstans, R., Boyles, M., Chandra, K., Chavez, M., Chen, G., Chudasama, B., Dodge, R., Fuller, R., Girard, M., Jiang, J., Jiang, Y., Knosp, B., LaBelle, R., Lam, J., Lee, K., Miller, D., Oswald, J., Patel, N., Pukala, D., Quintero, O., Scaff, D., Snyder, W. V., Tope, M., Wagner, P., and Walch, M.: The Earth Observing System Microwave Limb Sounder (EOS MLS) on the Aura satellite, IEEE Trans. Geosci. Remote Sens., 44(5), 1075-7092, 2006.

Wesley, M. J.: Parameterization of surface resistances to gazeous dry deposition in regional-scale numerical models, Atmos.Environ., 23, 1293-1304, 1989. 